\title{
Conventional, Enhanced, and Alkaline Coagulation for Hard Ghrib Dam (Algeria) Water
}

\author{
Souaad Djezzar ${ }^{1}$, Djamel Ghernaout ${ }^{2,3,}{ }^{*}$, Hakima Cherifi ${ }^{4}$, Abdulaziz Alghamdi ${ }^{5}$, \\ Badia Ghernaout $^{6}$, Mohamed Aichouni ${ }^{7}$ \\ ${ }^{1}$ Algerian Waters Company (ADE), Medea, Algeria \\ ${ }^{2}$ Chemical Engineering Department, College of Engineering, University of Ha'il, Ha'il, Saudi Arabia \\ ${ }^{3}$ Chemical Engineering Department, Faculty of Engineering, University of Blida, Blida, Algeria \\ ${ }^{4}$ Chemical Engineering Department, Faculty of Engineering, University of Medea, Medea, Algeria \\ ${ }^{5}$ Mechanical Engineering Department, College of Engineering, University of Ha'il, Ha'il, Saudi Arabia \\ ${ }^{6}$ Laboratory of Mechanics (LME), Department of Mechanical Engineering, University of Laghouat, Laghouat, Algeria \\ ${ }^{7}$ Industrial Engineering Department, College of Engineering, University of Ha'il, Ha'il, Saudi Arabia
}

Email address:

djamel_andalus@hotmail.com (D.Ghernaout)

${ }^{*}$ Corresponding author

\section{To cite this article:}

Souaad Djezzar, Djamel Ghernaout, Hakima Cherifi, Abdulaziz Alghamdi, Badia Ghernaout, Mohamed Aichouni. Conventional, Enhanced, and Alkaline Coagulation for Hard Ghrib Dam (Algeria) Water. World Journal of Applied Chemistry. Vol. 3, No. 2, 2018 , pp. $41-55$. doi: $10.11648 /$ j.wjac.20180302.12

Received: May 20, 2018; Accepted: June 1, 2018; Published: June 25, 2018

\begin{abstract}
This work aims to study coagulation process for hard Ghrib Dam (GD) water treatment. Conventional coagulation (CC), enhanced coagulation (EC) and alkaline coagulation (AC) experiments were realized on jar tests. This study demonstrated the effectiveness of GD water treatment by the EC process compared to $\mathrm{CC}$. Indeed, by CC, it has been demonstrated that each of the two coagulants studied (alum and $\mathrm{FeCl}_{3}$ ) is effective for remarkable reductions in OM of $36 \%$ and $47.4 \%$, respectively. However, EC, by slightly acidifying water, gave better removal efficiencies of the studied parameters. Indeed, the best abatement of OM is about $78 \%$ when water is treated with ferric chloride at $\mathrm{pH} 5.5$, lowered with nitric acid. The observed disadvantage here is the residual nitrate, which existed in the raw water at only low level. On the other hand, at the same $\mathrm{pH}$, the reduction of the $\mathrm{OM}$ is $64 \%$ when alum is used as coagulant. In addition, the data collected have led to the conclusion that the physicochemical quality of the GD water has a high salinity and lowering its $\mathrm{pH}$ (EC) does not affect it at all. On the other hand, its $\mathrm{pH}$ elevation (AC) considerably reduces its total hardness which is $41 \%$ with $\mathrm{NaOH}$. Such a performance advantageously positions this total hardness reduction technology among the possible solutions to the problems associated with total hardness.
\end{abstract}

Keywords: Conventional Coagulation (CC), Enhanced Coagulation (EC), Alkaline Coagulation, Alum, Lime; Ferric Chloride

\section{Introduction}

Water is the major element of the mineral and biological world. It is also the privileged vector of life and human activity. However, water in nature is often not directly usable for human consumption or for industry because it is not pure enough. Indeed, during its circulation on the surface of the Earth, water is polluted and carries dissolved and suspended matter: clay particles, waste of vegetation, living organisms (plankton, bacteria, viruses), various salts (nitrates, chlorides, sulfates, sodium carbonate, calcium carbonate, iron [1], manganese, etc.), organic materials (humic acids, fulvic acids, manufacturing residues, pesticides), and gases [2].

However, it is clear that elimination or inactivation of pathogenic microorganisms by filtration or disinfection has been and continues to be the key requirement for ensuring safe water [3]. The need to remove the compounds responsible for bad tastes and odors, whether of natural or artificial origin, 
becomes an important requirement that is additional to the burden of conventional treatment processes. Since the analytical methodology has been significantly improved and the contamination of the aquatic environment is more seriously taken into account, this leads to a growing interest in improved processes to remove these pollutants from water supplies [4].

Thus, coagulation/flocculation, decantation and filtration are irreplaceable processes in conventional treatment for the removal of solid particles and pathogenic microorganisms [5, 6]. Turbidity is considered as the best and rapid indicator of the efficiency of these processes. The regulatory norm regarding drinking water requires from water treatment plants to guarantee a turbidity of less than 5 (or even 0.1 ) NTU. This turbidity objective can be guaranteed for most water treatment plants at the end of filtration process [7-11].

However, turbidity is not the only parameter to control or optimize after the stage of filtration. In recent decades, special attention has been paid to the elimination of natural organic matter (NOM) as well as pathogenic microorganisms and algae.

The NOM present in raw water is a source of many inconveniences: colors, tastes or odors. It is also involved in the formation of disinfection by-products mainly during chlorination [12-15]. Finally, it interferes with the oxidation of dissolved iron and manganese, thus aggravating the corrosion of pipes and the deterioration of water quality in the distribution network. Eliminating NOM is therefore essential to avoid or minimize health risks and degradation of the distribution network.

Removing MON by enhanced coagulation (EC) requires the addition of high doses of inorganic coagulants and/or especially an acidic coagulation $\mathrm{pH}$ that may even lead to excessive concentrations of the residual metal at the end of the treatment, as well as strong sludge production [16, 17]. Concerning the elimination of the NOM, it can be better carried out, during or after decantation, by the addition of the powdered activated carbon (PAC) as an adsorbent. This step can be expensive because of the high costs of the PAC. The optimization of reagent treatment rates (acid/base, coagulant/flocculant, PAC, etc.) is therefore a technical and economic issue and vital for water treatment [18-20].

The aim of this study is eliminating NOM using EC process, which consists of reducing the $\mathrm{pH}$ of water before coagulation before adding different acids and finally performing a comparison between conventional coagulation (CC) and EC. Finally, the main results will be discussed.

\section{Materials and Methods}

\subsection{Presentation of the Ghrib Dam Water Treatment Plant (GDWTP)}

The Ghrib Dam (GD) (North of Algeria) is a real hydraulic structure built in 1939. The climate of the study area is generally Mediterranean and the precipitation regime is highly seasonal. The geological formations of the region consist mainly of sandstone and clay marls [21,22].

The GDWTP is fed from the GD. The development of GDWTP includes firstly a floating raw water intake in the reservoir of the GD which supplies a regulation basin. Secondly, the processing chain consists of two treatment streams that operate in parallel. The two treatment streams comprise a pre-oxidation unit, a coagulation-flocculation step followed by a decantation step, and a sand filtration step, and finally a post-disinfection step.

These two treatment streams are characterized by an identical process of treatment, the only difference being in their capacity. A treatment system that feeds the City of Medea (named stage III) whose nominal capacity is $24000 \mathrm{~m}^{3}$; while the treatment system that supplies the City of Berrouaghia (named stage II) has a nominal capacity of $12000 \mathrm{~m}^{3}$.

Water is taken from the reservoir by means of four electro-pumps which pump water to a control pond from which it is directly admitted by gravity to the treatment plant itself. The first stage comprises a mixing tank provided with a stirrer, to disperse the reagents, where sodium hypochlorite is added to water for the pre-oxidation process and aluminum sulfate $\left(\left(\mathrm{Al}_{2}\left(\mathrm{SO}_{4}\right)_{3} \cdot 18 \mathrm{H}_{2} \mathrm{O}\right)\right.$, alum $)$ is injected for the coagulation process. This basin is linked directly to another basin provided with more rapid agitation to properly destabilize the colloidal particles. After this step, the flocculation process takes place in three flocculators arranged in series: two are provided with a medium agitation (the first one to disperse the flocculant into water, and the second one to agglomerate the flocs), and the third one with a slow stirring (to do not break the formed flocs). The flocs formed are separated, subsequently, by settling in two circular decanters; the rest of the small flocs being eliminated by fast sand filtration (battery of four filters). Finally, the filtered water is chlorinated after admission to the treated water tank. It is from this reservoir that water is taken up and returned to the places of consumption via an adduction pipe.

Table 1 presents a brief description of the water treatment stages at the GDWTP.

Table 1. Technical presentation of the water treatment stages at the GDWTP.

\begin{tabular}{ll}
\hline Stage & Description \\
\hline Taking of water & $\begin{array}{l}\text { The raw water is withdrawn from the reservoir by means of four floating electro-pumps away from the station at } 200 \text { m. These } \\
\text { groups pump raw water over a control pond. }\end{array}$ \\
& $\begin{array}{l}\text { The raw water is stored in the regulation basin to distribute it into the treatment channels. With a capacity of } 1100 \mathrm{~m}^{3} \text {, this basin } \\
\text { is also considered as a primary settler which allows eliminating certain fractions of the clays and sand sucked by the pumps, by } \\
\text { simple decantation. }\end{array}$ \\
& $\begin{array}{l}\text { From the regulation basin to the mixing basin, the pre-clarified water arrives gravitationally. In this basin, chemical injection is } \\
\text { done: sodium hypochlorite for pre-chlorination and alum for coagulation. The incoming raw water flow is } 600 \mathrm{~m}^{3} \text { for Stage III } \\
\text { and } 450 \mathrm{~m}^{3} \text { for Stage II. } \\
\text { Coagulation process }\end{array}$ \\
\hline
\end{tabular}




\begin{tabular}{|c|c|}
\hline Stage & Description \\
\hline \multirow{15}{*}{ Flocculation process } & a chemical called coagulant which is alum: \\
\hline & Number of basins: $2+1$ \\
\hline & Area: $2 \times 4 \mathrm{~m}^{2}+4 \mathrm{~m}^{2}$ \\
\hline & Unit volume: $2 \times 12 \mathrm{~m}^{3}+12 \mathrm{~m}^{3}$ \\
\hline & Fast agitation: $180 \mathrm{rpm}$ \\
\hline & Residence time: $2 \mathrm{~min}$ \\
\hline & Injection point: Mixing basin \\
\hline & $\begin{array}{l}\text { The flocculation process aims to increase the volume and cohesion of the flocs previously formed by coagulation. During a } \\
\text { gentle mixing, it consists of adding a flocculation adjuvant that forms "bridges" between the flocs: }\end{array}$ \\
\hline & Number of basins: $6+3$ \\
\hline & Area: $6 \times 4 \mathrm{~m}^{2}+3 \times 4 \mathrm{~m}^{2}$ \\
\hline & Unit volume: $6 \times 12 \mathrm{~m}^{3}+3 \times 12 \mathrm{~m}^{3}$ \\
\hline & Medium agitation: $90 \mathrm{rpm}(4+2)$ \\
\hline & Slow agitation: $40 \mathrm{rpm}(2+1)$ \\
\hline & Residence time: $18 \mathrm{~min}$ \\
\hline & Injection point: First medium agitation basin of flocculation \\
\hline \multirow{8}{*}{ Decantation process } & Decantation is a process of separation of formed flocs, suspended solids, and colloids whose density is greater than that of water. \\
\hline & The clarified water near the surface is directed to the filters: \\
\hline & Number of decanters: $2+2$ \\
\hline & Type: Circular \\
\hline & Diameter: $2 \times 6 \mathrm{~m}+2 \times 4 \mathrm{~m}$ \\
\hline & Unit volume: $2 \times 890 \mathrm{~m}^{3}+2 \times 460 \mathrm{~m}^{3}$ \\
\hline & Area: $2 \times 194.3 \mathrm{~m}^{2}+2 \times 164.7 \mathrm{~m}^{2}$ \\
\hline & Sludge extraction rate: $23.5 \mathrm{~m}^{3} / \mathrm{h}+15 \mathrm{~m}^{3} / \mathrm{h}$ \\
\hline \multirow{7}{*}{ Sand filtration } & $\begin{array}{l}\text { Filtration is a separation process that uses the passage of a solid-liquid mixture through a porous medium (filter). Filtration } \\
\text { retains solid particles and allows the liquid (filtrate) to pass. }\end{array}$ \\
\hline & Sand filters: \\
\hline & Number of filters: $8+4$ \\
\hline & Length: $6 \mathrm{~m}+6 \mathrm{~m}$ \\
\hline & Width: $3 m+3 m$ \\
\hline & Area: $8 \times 24.5 \mathrm{~m}^{2}+4 \times 24.5 \mathrm{~m}^{2}$ \\
\hline & Maximum filtration speed: 5 to $10 \mathrm{~m} / \mathrm{h}$ \\
\hline \multirow{6}{*}{ Disinfection basin } & $\begin{array}{l}\text { The filtered water is chlorinated with sodium hypochlorite at } 48^{\circ} \text {. To obtain a durable disinfection, it is necessary that the } \\
\text { chlorine dose administered is such that it is possible to detect certain residual free chlorine content after a determined contact } \\
\text { time. }\end{array}$ \\
\hline & Number: $1+1$ \\
\hline & Capacity: $760 \mathrm{~m}^{3}+360 \mathrm{~m}^{3}$ \\
\hline & Basin area: $165 \mathrm{~m}^{2}+80 \mathrm{~m}^{2}$ \\
\hline & Depth: $3 \mathrm{~m}+3 \mathrm{~m}$ \\
\hline & Residence time: $30 \mathrm{~min}$ \\
\hline Alum dosage & $\begin{array}{l}\text { Alum is delivered in bags in the form of aggregates. For the dosage, the preparation of an aqueous solution is done by mixing the } \\
\text { grains and water at a rate of } 100 \mathrm{~kg} / \mathrm{m}^{3} \text {. The injection is carried out directly in the mixing basin. The dose of the injection applied } \\
\text { is determined after jar test experiments (the average optimal dose of alum: } 30 \mathrm{~g} / \mathrm{m}^{3} \text { ). }\end{array}$ \\
\hline Polyelectrolytes dosage & $\begin{array}{l}\text { Polyelectrolytes are delivered in bags in the form of aggregates. For the dosage, the preparation of an aqueous solution is done by } \\
\text { mixing grains and water at a rate of } 1 \mathrm{Kg} / \mathrm{m}^{3} \text {. The injection takes place directly in the flocculation basin (medium agitation); the } \\
\text { dose of the injection applied is determined after jar test experiments (the average optimal dose of polyelectrolytes: } 0.2 \mathrm{~g} / \mathrm{m}^{3} \text { ). }\end{array}$ \\
\hline $\begin{array}{l}\text { Sodium hypochlorite } \\
\text { dosage }\end{array}$ & $\begin{array}{l}\text { Sodium hypochlorite is delivered in liquid form. The injection of sodium hypochlorite into water, for pre-chlorination and } \\
\text { disinfection, is done after a chlorine demand (CD) test whose optimal dose is } 24 \mathrm{~mL} / \mathrm{m}^{3} \text { and } 16 \mathrm{~mL} / \mathrm{m}^{3} \text {, respectively. }\end{array}$ \\
\hline
\end{tabular}

\subsection{Sampling Methods}

The natural water source used in this study is GD water. The quality parameters of the raw water over a 7 month period are performed. From these surface waters, a daily production of about $34000 \mathrm{~m}^{3}$ of drinking water is provided to the cities of Medea and Berrouaghia. The raw water samples were collected for our work in limited quantities and periodically from the control basin and transported to the ADE Laboratory on the same day. When samples were received at the laboratory, they were kept cool and dark in order to delay biological activity before analysis.

\subsection{Jar Test Experiments Procedure}

To determine the optimal coagulation conditions, a series of laboratory-scale tests were used. Experiments on samples of 1 L were carried out using a test apparatus ("Floc Tester/Aqualytic") which makes it possible to obtain, in five beakers of 1 liter of water, rigorously identical and adjustable agitation during the same period thanks to a central control. The standard jar test procedure involves injecting increasing amounts of coagulant and mixing rapidly at $200 \mathrm{rpm}$ for $3 \mathrm{~min}$, slow mixing at $60 \mathrm{rpm}$ for $17 \mathrm{~min}$, and settling for $30 \mathrm{~min}$. To evaluate the performance of the treatment: (1) the formed flocs are observed (time of appearance, size, and appearance); (2) the volumes and masses of the sludge formed are compared; (3) by siphoning, a sample is taken for analysis of 
the supernatant in each beaker while avoiding sucking the sludge.

\subsection{Used Products}

The doses of ferric chloride $\left(\mathrm{FeCl}_{3} \cdot 6 \mathrm{H}_{2} \mathrm{O}\right)$ and aluminum sulfate $\left(\left(\mathrm{Al}_{2}\left(\mathrm{SO}_{4}\right)_{3} .18 \mathrm{H}_{2} \mathrm{O}\right)\right.$, alum) were varied between $10-50$ $\mathrm{mg} / \mathrm{L}$ prepared from a stock solution of $10 \mathrm{~g} / \mathrm{L}$ which is prepared periodically. For lowering $\mathrm{pH}$, three acids $(0.1 \mathrm{~N})$ were used separately: sulfuric acid $\left(\mathrm{H}_{2} \mathrm{SO}_{4}\right)$, hydrochloric acid $(\mathrm{HCl})$, and nitric acid $\left(\mathrm{HNO}_{3}\right)$. In order to increase $\mathrm{pH}$, sodium hydroxide $(\mathrm{NaOH})$, at $0.1 \mathrm{~N}$, or lime water $\left(\mathrm{Ca}(\mathrm{OH})_{2}\right)$, at 1.6 $\mathrm{g} / \mathrm{L}$, were used. All chemicals used in this study are of analytical grade.

\subsection{Analytical Methods}

A total of 29 variables were subject to physicochemical monitoring. They are determined by colorimetric, volumetric, gravimetric, nephelometric, photometric, and potentiometric analytical methods. The bacteriological examinations carried out concern the enumeration of pollution indicator germs which are: total coliforms, fecal coliforms, fecal streptococci, and sulfite-reducing clostridiums. The method used is that of membrane filtration. The various characteristics of the water samples were determined according to the standard methods of analysis $[23,24]$. The details of the analytical methods and the equipment used are presented in Table 2.

Table 2. Analytical methods of the parameters studied.

\begin{tabular}{|c|c|}
\hline Parameter & Method \\
\hline Electrical conductivity (conductivity meter WTW LF 197) & [23] \\
\hline Turbidity, nephelometric method (HACH turbidimeter) & ISO 7027-1:2016 \\
\hline Temperature (WTW LF 197) & [23] \\
\hline $\mathrm{pH}$, electrometric determination ( $\mathrm{pH}-$ meter HANNA) & [23] \\
\hline Calcium $\left(\mathrm{Ca}^{2+}\right)$, titrimetric method with ethylenediaminetetraacetic acid (EDTA) & ISO 6058:1984 \\
\hline Magnesium $\left(\mathrm{Mg}^{2+}\right)$, titrimetric method with EDTA & ISO 6058:1984 \\
\hline Chlorides $\left(\mathrm{Cl}^{-}\right)$(Mohr method) & ISO 9297:1989 \\
\hline Total hardness, titrimetric method with EDTA & [23] \\
\hline Oxidability with potassium permanganate $\left(\mathrm{KMnO}_{4}\right)$ (permanganate index $)$ & ISO $8467: 1993$ \\
\hline Sodium $\left(\mathrm{Na}^{+}\right)$and potassium $\left(\mathrm{K}^{+}\right)$, flame photometry method (CORNING) & ISO 9964-3:1993 \\
\hline Nitrates $\left(\mathrm{NO}_{3}{ }^{-}\right)$, spectrophotometric method (UV-Vis SPECOL spectrophotometer) & ISO 7890-3:1988 \\
\hline Nitrites $\left(\mathrm{NO}_{2}^{-}\right)$, spectrophotometric method (UV-Vis SPECOL spectrophotometer) & [23] \\
\hline Ammonia nitrogen $\left(\mathrm{NH}_{4}^{+}\right)$(ammonium), spectrophotometric method (UV-Vis SPECOL spectrophotometer) & ISO $7150-1: 1984$ \\
\hline Phosphates $\left(\mathrm{PO}_{4}^{3-}\right)$, spectrophotometric method (UV-Vis SPECOL spectrophotometer) & ISO 6878:2004 \\
\hline Iron (Fe), spectrophotometric method (UV-Vis SPECOL spectrophotometer) & ISO 6332:1988 \\
\hline Sulfates $\left(\mathrm{SO}_{4}{ }^{2-}\right)$, spectrophotometric method (UV-Vis SPECOL spectrophotometer) & [23] \\
\hline Chemical oxygen demand (COD) & ISO $6060 / 1989-10-15$ \\
\hline Biological oxygen demand $\left(\mathrm{BOD}_{5}\right)(\mathrm{AQUA}$ Lytic BOD meter) & [23] \\
\hline Chlorophyll $a$, spectrophotometric method (UV-Vis SPECOL spectrophotometer) & [23] \\
\hline Dry residue, gravimetric method & [23] \\
\hline Total coliforms & [23] \\
\hline Fecal coliforms & [23] \\
\hline Fecal streptococci & ISO 7899-1:1998 \\
\hline Clostridium sulfito-reducer & ISO 6222:1999 \\
\hline Salmonella typhi & {$[23]$} \\
\hline Cholera vibrio & [23] \\
\hline
\end{tabular}

\section{Results and Discussion}

This study was performed from February to August 2012. Physicochemical and bacteriological analyses were performed to evaluate the contents of GD water.

\subsection{Physicochemical and Bacteriological Parameters of GD Water}

The results of physicochemical analyzes of GD water are reported in Table 3.

Table 3. Physicochemical analyzes of GD water.

\begin{tabular}{|c|c|c|c|c|c|c|c|c|}
\hline \multirow{2}{*}{ Parameter } & \multicolumn{7}{|c|}{ Month (2012) } & \multirow{2}{*}{$\begin{array}{l}\text { Parametric } \\
\text { value }[25]\end{array}$} \\
\hline & February & Mars & April & May & June & July & August & \\
\hline Electrical conductivity $\left(\mu \mathrm{S} / \mathrm{cm}, 25^{\circ} \mathrm{C}\right)$ & 3250 & 3250 & 3080 & 3200 & 3240 & 3250 & 3320 & $2500^{* *}$ \\
\hline Dry residue $(\mathrm{mg} / \mathrm{L})$ & 2157 & 2160 & 2004 & 2175 & 2204 & 2210 & 2250 & \\
\hline Total hardness (mg/L) & 955 & 745 & 625 & 630 & 655 & 769 & $\mathrm{nd}^{*}$ & \\
\hline $\mathrm{Mg}^{2+}(\mathrm{mg} / \mathrm{L})$ & 216 & 229 & 179 & 150 & 151 & 157 & 184 & $50^{* * * *}$ \\
\hline $\mathrm{Ca}^{2+}(\mathrm{mg} / \mathrm{L})$ & 210 & 198 & 158 & 148 & 146 & 152 & 148 & \\
\hline $\mathrm{Cl}^{-}(\mathrm{mg} / \mathrm{L})$ & 428 & 337 & 415 & 530 & 532 & 530 & 453 & $250^{* * *}$ \\
\hline $\mathrm{SO}_{4}^{2-}(\mathrm{mg} / \mathrm{L})$ & 769 & 998 & 352 & 394 & 393 & 392 & 523 & \\
\hline $\mathrm{Na}^{+}(\mathrm{mg} / \mathrm{L})$ & 265 & 280 & 320 & 385 & 387 & 386 & 292 & $200^{* * * *}$ \\
\hline
\end{tabular}




\begin{tabular}{|c|c|c|c|c|c|c|c|c|}
\hline \multirow{2}{*}{ Parameter } & \multicolumn{7}{|c|}{ Month (2012) } & \multirow{2}{*}{$\begin{array}{l}\text { Parametric } \\
\text { value [25] }\end{array}$} \\
\hline & February & Mars & April & May & June & July & August & \\
\hline $\mathrm{K}^{+}(\mathrm{mg} / \mathrm{L})$ & 8 & 6 & 8 & 8 & 8 & 8 & 8 & \\
\hline $\mathrm{pH}$ & 8 & 7.4 & 8 & 7.7 & 8 & 8 & 8.1 & $6.5-8.5^{* * * *}$ \\
\hline Total alkalinity $\left(\mathrm{mg} / \mathrm{L}\right.$ as $\left.\mathrm{CaCO}_{3}\right)$ & 110 & 110 & 123 & 110 & 102 & 105 & 100 & \\
\hline Turbidity (NTU) & 6.53 & 6.53 & 7.55 & 6.66 & 4.73 & 7.31 & 8.47 & \\
\hline $\mathrm{KMnO}_{4}$ oxidability $(\mathrm{mg} / \mathrm{L})$ & 7.2 & 6.5 & 6.8 & 7.3 & 8 & 9.7 & 9.8 & \\
\hline $\mathrm{COD}(\mathrm{mg} / \mathrm{L})$ & 37 & 13 & 38 & 19.6 & 19.8 & 19 & 19 & \\
\hline $\mathrm{COD} / \mathrm{BOD}_{5}$ & 7.4 & 2.6 & 19 & 4.9 & 3.3 & 2.2 & 2.2 & \\
\hline $\mathrm{NO}_{3}^{-}(\mathrm{mg} / \mathrm{L})$ & $\mathrm{nd}^{*}$ & 4 & 3.2 & 5.6 & 3.8 & 4.3 & 4.2 & $50^{* * *}$ \\
\hline GD volume $\left(\mathrm{Mm}^{3}\right)$ & 95 & 103 & 136 & 127 & 125 & 118 & 109 & \\
\hline GD water temperature $\left({ }^{\circ} \mathrm{C}\right)$ & 8.1 & 11.7 & 14.7 & 20.2 & 23.8 & 26.5 & 26.5 & \\
\hline GD air temperature $\left({ }^{\circ} \mathrm{C}\right)$ & 15 & 22 & 17 & 32 & 30 & 41 & 26 & \\
\hline Chlorophyll $a(\mu \mathrm{g} / \mathrm{L})$ & 0.9 & 0.8 & 1 & 1.6 & 1.2 & 2 & 2.9 & \\
\hline Total coliforms $(/ 100 \mathrm{~mL})$ & 3850 & 2778 & 4100 & 3100 & 4962 & 5040 & 5378 & \\
\hline Clostridium sulfito-reducer $(/ 20 \mathrm{~mL})$ & 1 & 0 & 0 & 6 & 15 & 1 & 1 & \\
\hline
\end{tabular}

*nd: Not determined.

${ }^{* *} 2500 \mu \mathrm{S} / \mathrm{cm}$ at $20^{\circ} \mathrm{C}$ (European Union).

${ }^{* * *} \mathrm{Cl}^{-}$(European Union).

${ }^{* * * *}$ Canada.

By analyzing the values of the electrical conductivity which is in direct relation with the dry residue, GD water is mineralized but does not present a large variation during the year. This high mineralization is due to elevated levels of dissolved salts including sodium and potassium chlorides, sulfates, and calcium and magnesium hardness. These are at above-standard rates with more or less stable concentrations during the year and are directly related to the geological nature of the GD watershed. An inflection of the conductivity is observed during the months of March, April and May. This is explained by the dilution phenomenon following the rainfall and snowfall (February) on the watershed. The high hardness is attributed to the presence of the "blue marl" rock (a sedimentary rock containing $\mathrm{CaCO}_{3}$ limestone and clay) which constitutes the bottom of the GD. Also, from a concentration of $100 \mathrm{mg} / \mathrm{L}$, magnesium gives the water a bitter taste [23]. The water analysis shows high concentrations of chloride ions $\left(\mathrm{Cl}^{-}\right)$compared to the standards in force $(<250$ $\mathrm{mg} / \mathrm{L}$ ). This content could be explained by the nature of the land in the watershed located on saline soil and by wastewater discharges. GD water has high sulfate concentrations. The geology of the dam is marked by the absence of gypseous rocks and pyrites suggesting that the origin of these very high levels in sulfate is probably due to the release of water from the Boughezoul Dam (near GD). The sodium content is important. It depends on the terrain crossed mainly sedimentary rock that gives the water a salty taste. The potassium content is low and poses no problem as for its consumption. It is found that the GD water is slightly alkaline. The total alkalinity has more or less stable values. The alkalinity of water corresponds to the presence of hydroxide ions, carbonates and bicarbonates; and to a lesser extent to phosphate and silicate ions.

It is the particles in suspension which are at the origin of the turbidity [26]. Indeed, the erosion of the rocks, the training of the mineral and organic matter (OM) of the soil, the discharge of the wastewater can inevitably lead to the increase of the turbidity. According to the obtained results, the turbidity is rather weak since the water sampling is done on the surface.

The GD water contains amounts of OM (measured in terms of $\mathrm{KMnO}_{4}$ oxidability) (between 6.5 and $9.8 \mathrm{mg} \mathrm{O} / \mathrm{L}$ ). According to Rodier [23], water is of poor quality if its $\mathrm{KMnO}_{4}$ oxidability is greater than $4 \mathrm{mg} / \mathrm{L}$. The OM could come from pollution either of endogenous origin, generated during the biological processes within the medium, mainly, the algal excretion, cell lysis, or of exogenous origin brought by the urban discharges, the agricultural practices or soil leaching. These OM amounts can complicate the treatment of water with the formation of disinfection by-products, since there is a pre-oxidation at the beginning (treatment with chlorine) [27].

During the study period, the results of the COD show that the maximum load $\left(38 \mathrm{mg} \mathrm{O}_{2} / \mathrm{L}\right)$ does not largely exceed the guideline value which is $30 \mathrm{mg} / \mathrm{L}$ maximum [23]. The same remark is about the results obtained for the $\mathrm{BOD}_{5}$.

Nitrates are at levels of the order of $5.6 \mathrm{mg} / \mathrm{L}$. These concentrations are much lower than the maximum acceptable concentration according to the European Union Standards which is of the order of $50 \mathrm{mg} / \mathrm{L}$.

Exceptionally in this year 2012, in GD raw water, the ammonium, nitrite and phosphate levels are almost zero. This is explained by the climatic conditions experienced by the region in winter and early spring (the overflow of the Grib Dam Lake due to heavy rainfall and significant melting of snow). Indeed, on April 19, 2012, the water level exceeded the maximum of 136,476 million $\mathrm{m}^{3}$ and ended up overflowing via the large spillway.

The temperature of the surface waters is largely conditioned by the temperature of air and the solar energy. The water temperature of GD varies between $8.1^{\circ} \mathrm{C}$ in February and $26.5^{\circ} \mathrm{C}$ in August.

The chlorophyll $a$ content is clearly influenced by several 
factors such as the composition and physiological state of the algae, the cell density, the light, the temperature of water, and the time of day at which sample is taken. Chlorophyll $a$ levels were low during the study period, ranging from 0.81 to 2.9 $\mu \mathrm{g} / \mathrm{L}$. This is due to the climatic conditions mentioned above.

As for total coliforms, their number is significant but without exceeding the usual content of raw water for treatment for the production of drinking water. As for fecal coliforms, the analyzes carried out mention a low concentration, the maximum of which does not exceed $15 / 100 \mathrm{~mL}$ in the month of July. For fecal streptococci, no detections were recorded during the cold period. Then, a sudden onset of concentrations of 22, 50 and 35 in $100 \mathrm{~mL}$ of water in the months of June, July, and August, respectively. This is explained by the rise in temperature in this season. Clostridial sulphite-reducing spores are not as numerous; we have two peaks of 6 and 15 spores/20 mL in May and June, respectively (Table 2).

\subsection{CC with Ferric Chloride and Alum}

The removal of organic precursors by the coagulation process is influenced by several factors such as coagulation conditions and NOM characteristics [28, 29]. The choice of coagulant is a key factor in the performance of the coagulation process [30]. For this reason, the efficiency of ferric chloride was compared to that of alum. The comparative study on these two coagulants was carried out without adjusting $\mathrm{pH}$ of the raw water. The following parameters were evaluated: turbidity (Figure 1), OM (Figure 2), CD (Figure 3), and COD (Figure 4).

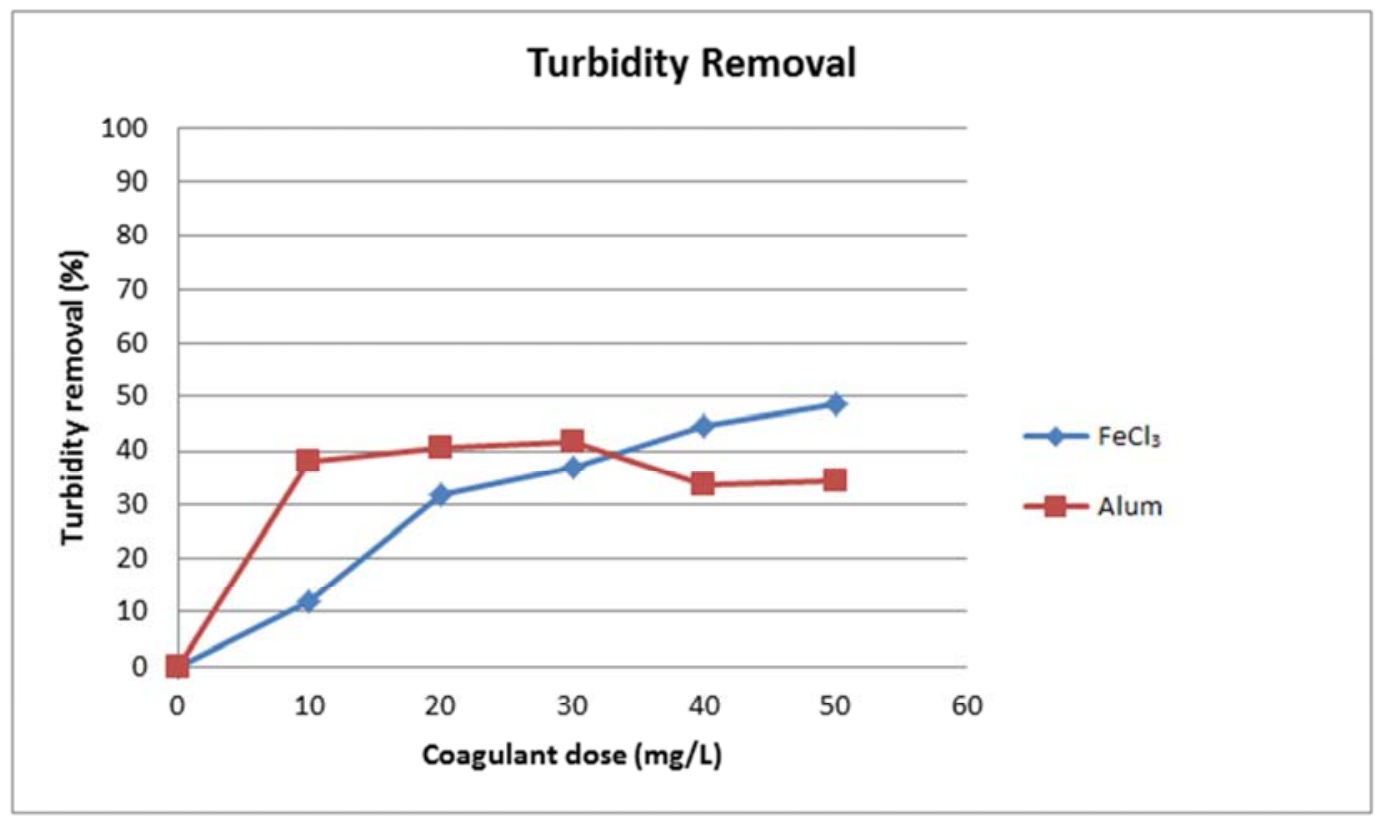

Figure 1. Reduction of the water turbidity of GD as a function of the dose of the coagulant (alum and ferric chloride).

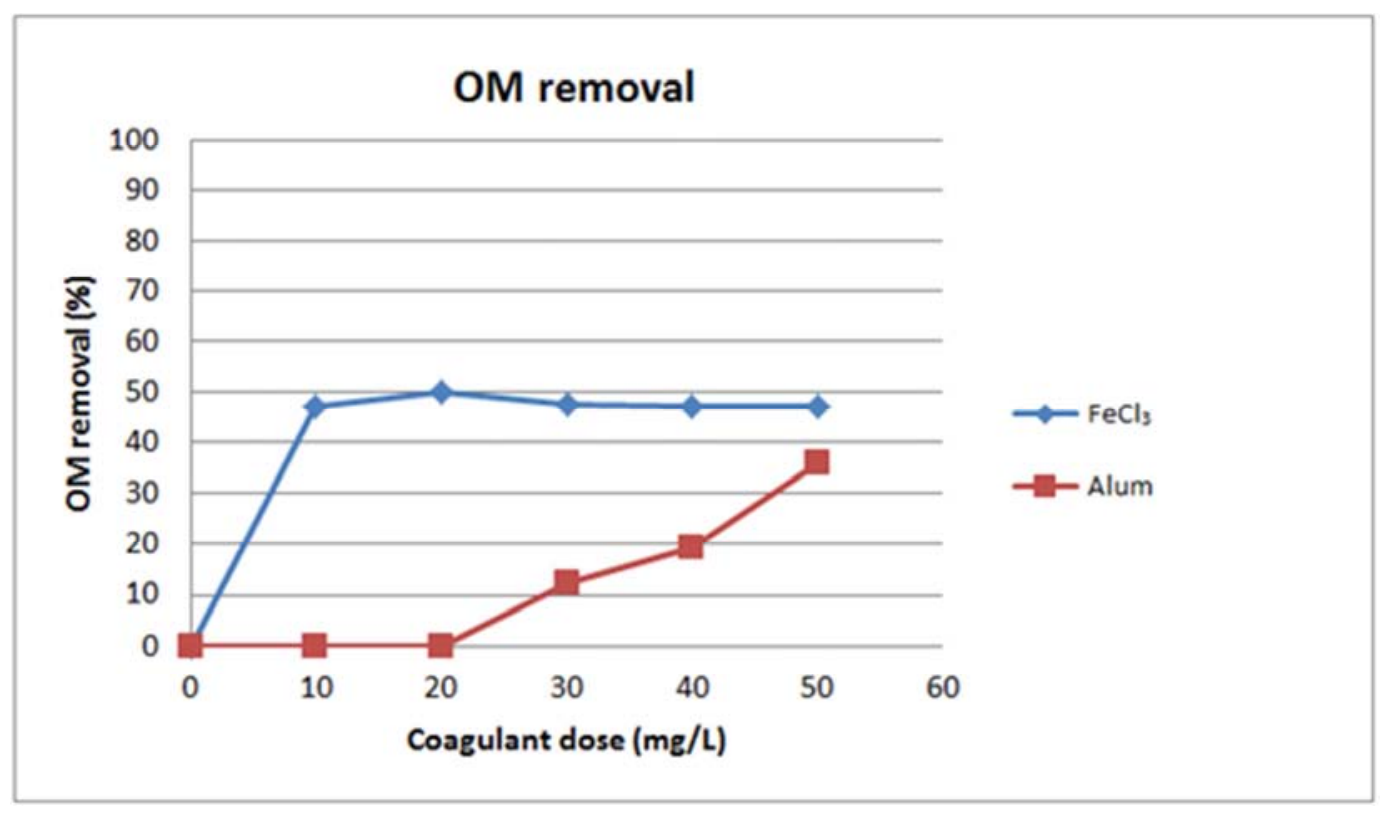

Figure 2. Reduction of the OM of GD water as a function of the dose of the coagulant (alum and ferric chloride). 


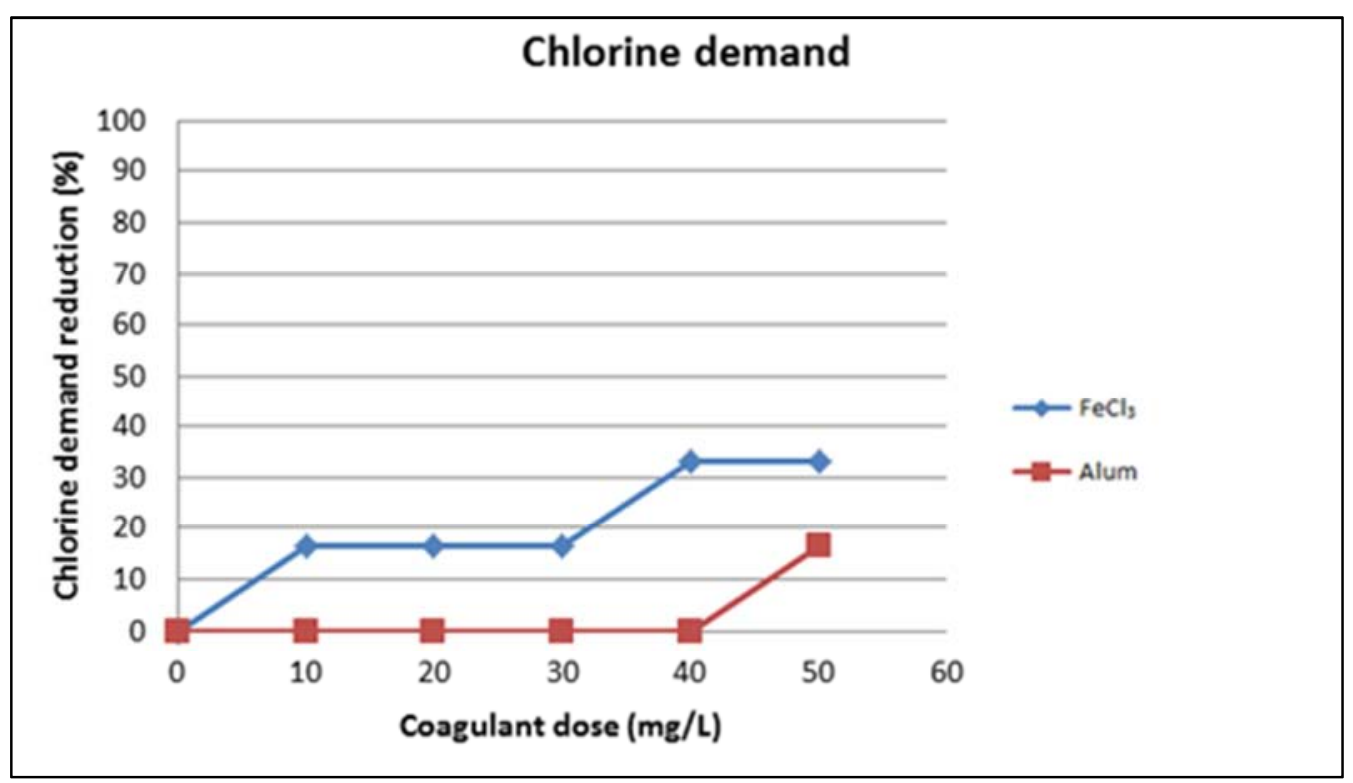

Figure 3. Reduction of $C D$ of GD water as a function of the dose of the coagulant (alum and ferric chloride).

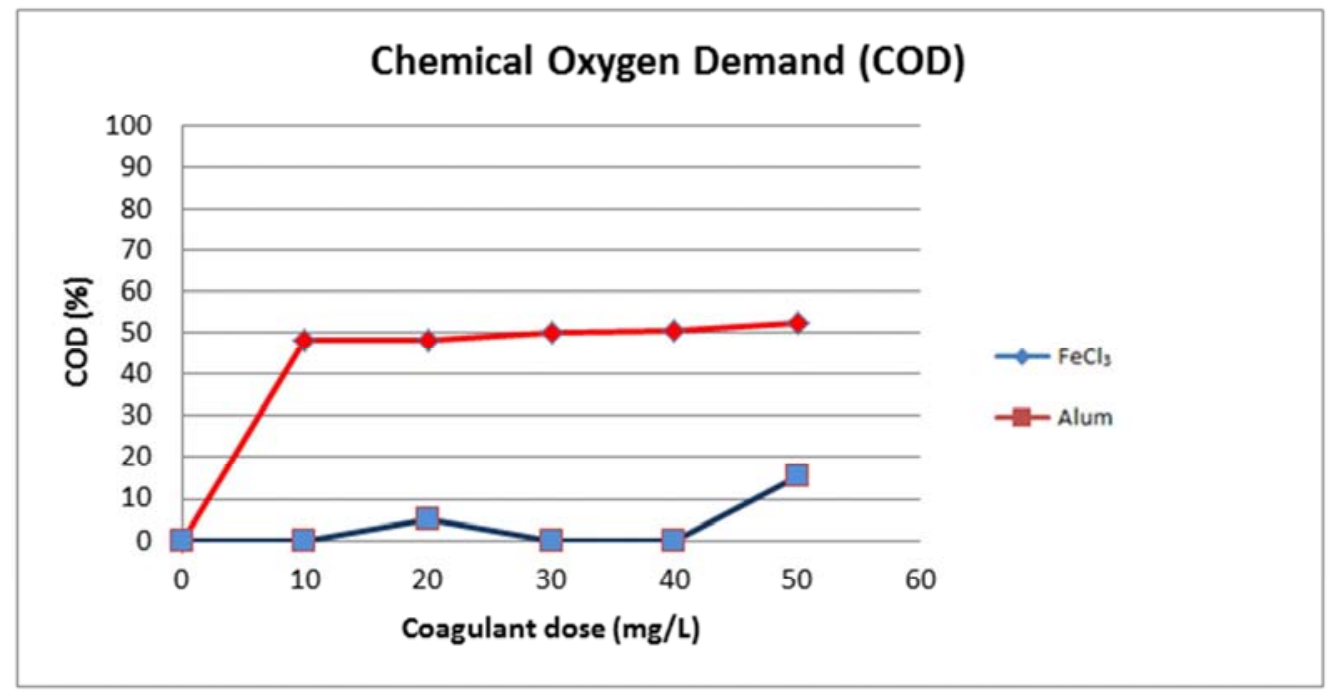

Figure 4. Reduction of the COD of GD water as a function of the dose of the coagulant (alum and ferric chloride).

Table 4. Optimum yield following the two coagulants used for the CC of GD water.

\begin{tabular}{lll}
\hline \multirow{2}{*}{ Parameter } & \multicolumn{2}{l}{$\begin{array}{l}\text { Efficiency (\%) of the coagulant at 50 } \\
\text { mg/L }\end{array}$} \\
\cline { 2 - 3 } & Alum & Ferric chloride \\
\hline OM (KMnO 4 oxidability) & 36 & 47 \\
Turbidity & 34 & 36 \\
$\mathrm{COD}$ & 15 & 52 \\
$\mathrm{CD}$ & 17 & 33 \\
$\mathrm{BOD}_{5}$ & 100 & 100 \\
Total coliforms & 17 & 90 \\
Fecal coliforms & 80 & 100 \\
Fecal streptococci & 100 & 100 \\
Clostridium sulfito-reducer & 100 & 100 \\
Chlorophyll $a$ & 68 & 72 \\
\hline
\end{tabular}

Several studies have shown a better performance for ferric chloride than for alum.

As shown in Figures. 1-4, the coagulation data indicate that as each dosage of coagulants increased further, the amount of removal was also increased gradually [31]. An average coagulant dosage was found in the vicinity of $30 \mathrm{mg} / \mathrm{L}$ (this is the dose used at the GDWTP). Although this dose gave satisfactory results, a coagulant dose of $50 \mathrm{mg} / \mathrm{L}$ was chosen for the EC studies since it gave better results. The $50 \mathrm{mg} / \mathrm{L}$ dose of the two coagulants allows a better reduction of everything related to coagulation: turbidity, $\mathrm{OM}, \mathrm{COD}, \mathrm{CD}$, $\mathrm{BOD}_{5}$, chlorophyll $a$, and microbial flora. The reduction rates of these parameters are listed in Table 4.

\subsection{EC with Ferric Chloride and Alum}

Determining EC conditions requires the evaluation of both optimal $\mathrm{pH}$ and coagulant dosage. To determine the optimal $\mathrm{pH}$ for a selected coagulant dose (alum and ferric chloride), the jar tests were performed using a constant coagulant dose and varying the $\mathrm{pH}$ of the coagulation using sulfuric acid, hydrochloric acid, and nitric acid. 


\subsubsection{Alum Experiments}

For alum, the optimal $\mathrm{pH}$ of coagulation was identified as the
$\mathrm{pH}$ at which there was the highest removal of turbidity (Figure 5), OM (Figure 6), CD (Figure 7), and COD (Figure 8).

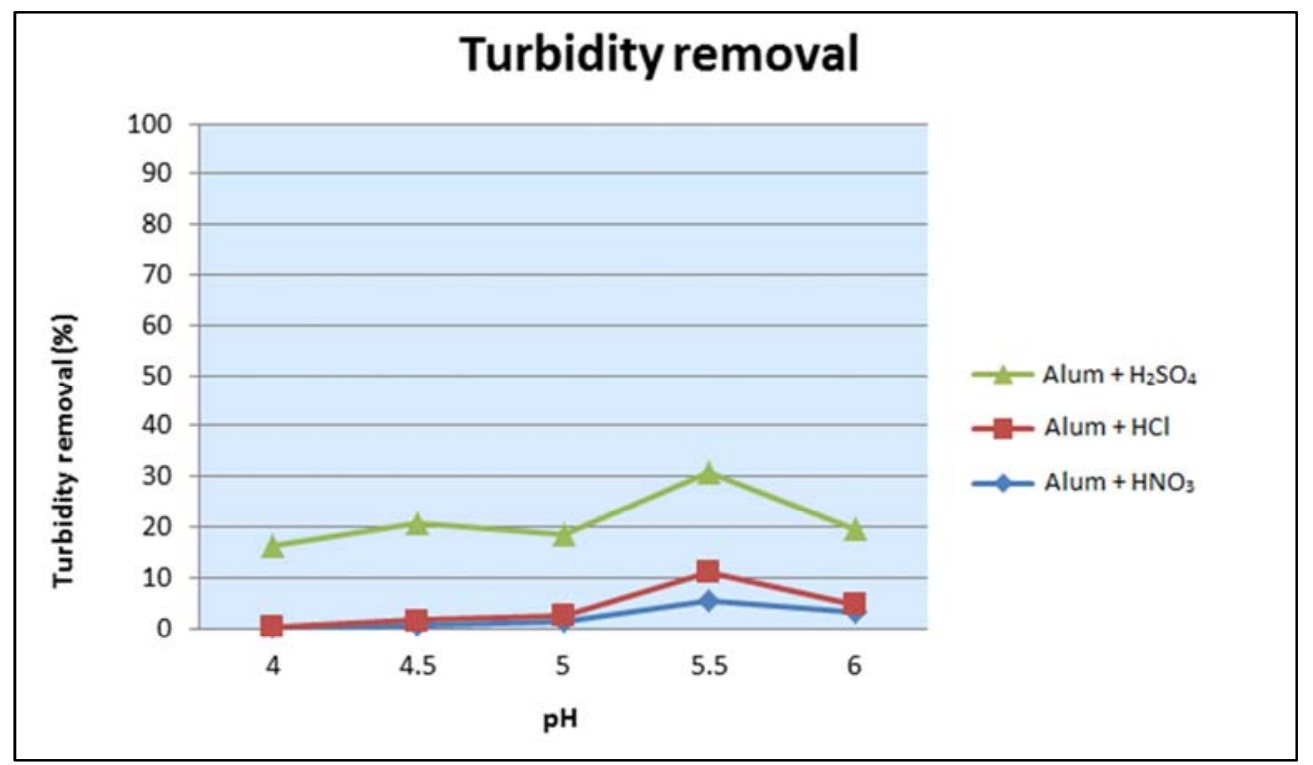

Figure 5. Reduction of turbidity as a function of $\mathrm{pH}\left(\mathrm{HCl}, \mathrm{HNO}_{3}\right.$ and $\left.\mathrm{H}_{2} \mathrm{SO}_{4}\right)$ with a fixed dose of alum.

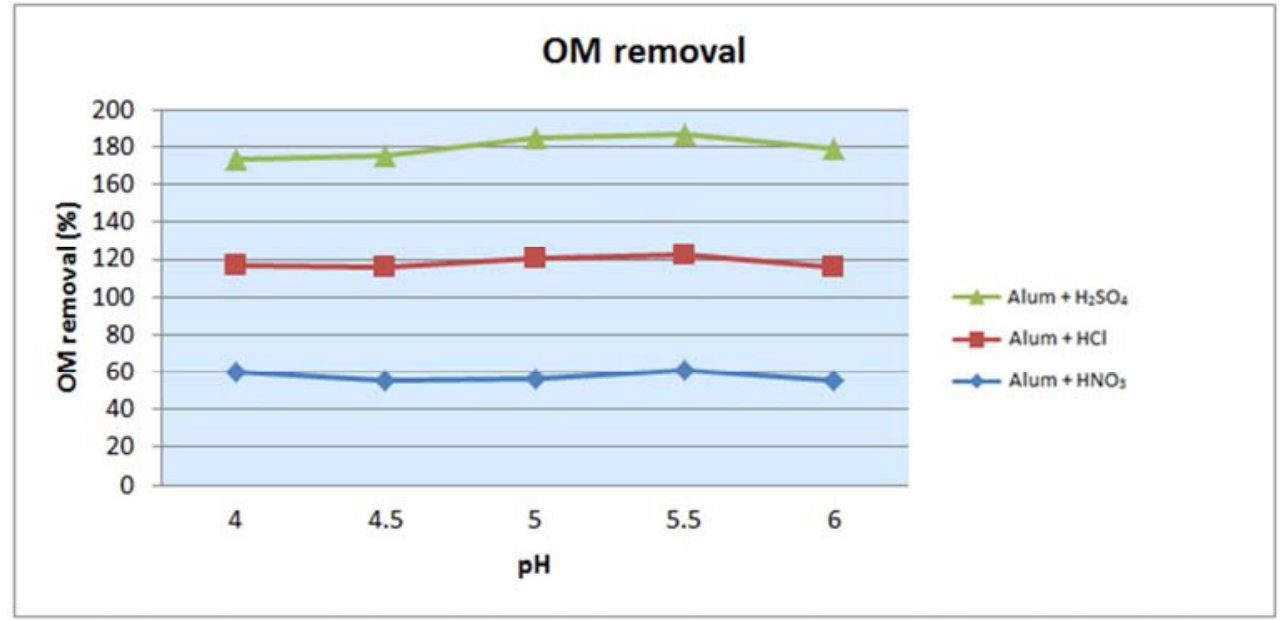

Figure 6. Reduction of OM as a function of $\mathrm{pH}\left(\mathrm{HCl}, \mathrm{HNO}_{3}\right.$ and $\left.\mathrm{H}_{2} \mathrm{SO}_{4}\right)$ with a fixed dose of alum.

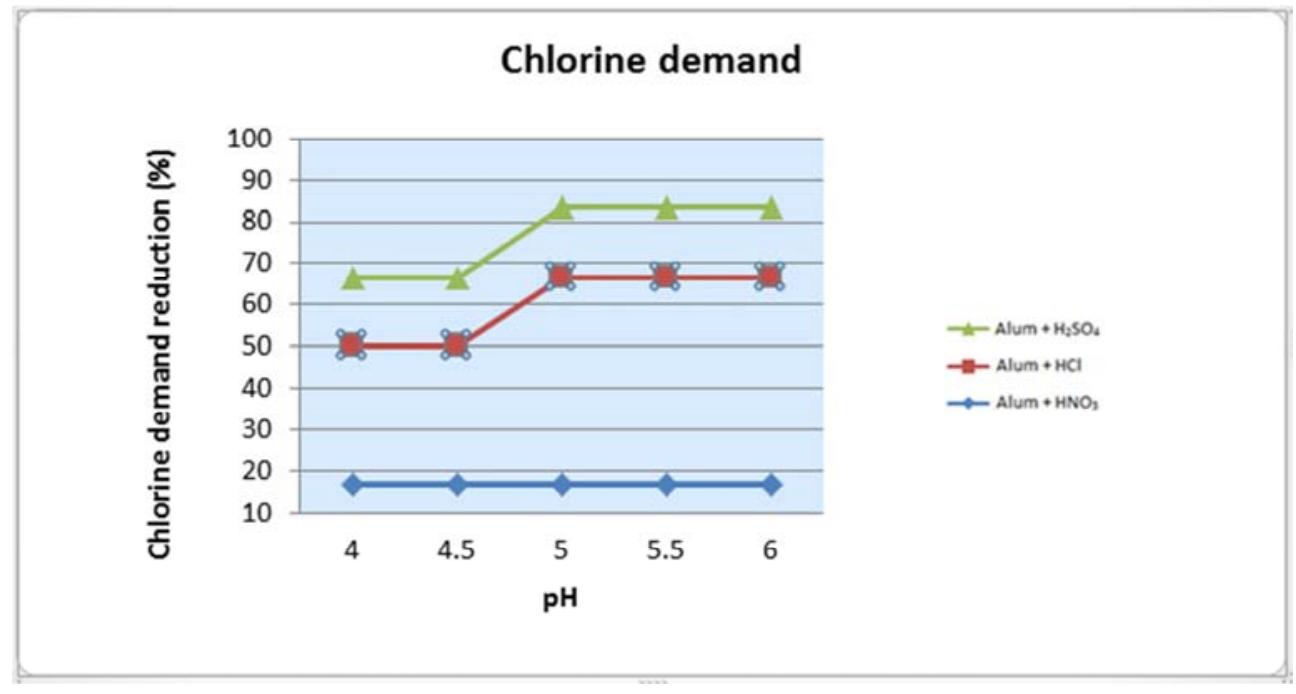

Figure 7. Reduction of $\mathrm{CD}$ as a function of $\mathrm{pH}\left(\mathrm{HCl}, \mathrm{HNO}_{3}\right.$ and $\left.\mathrm{H}_{2} \mathrm{SO}_{4}\right)$ with a fixed dose of alum. 


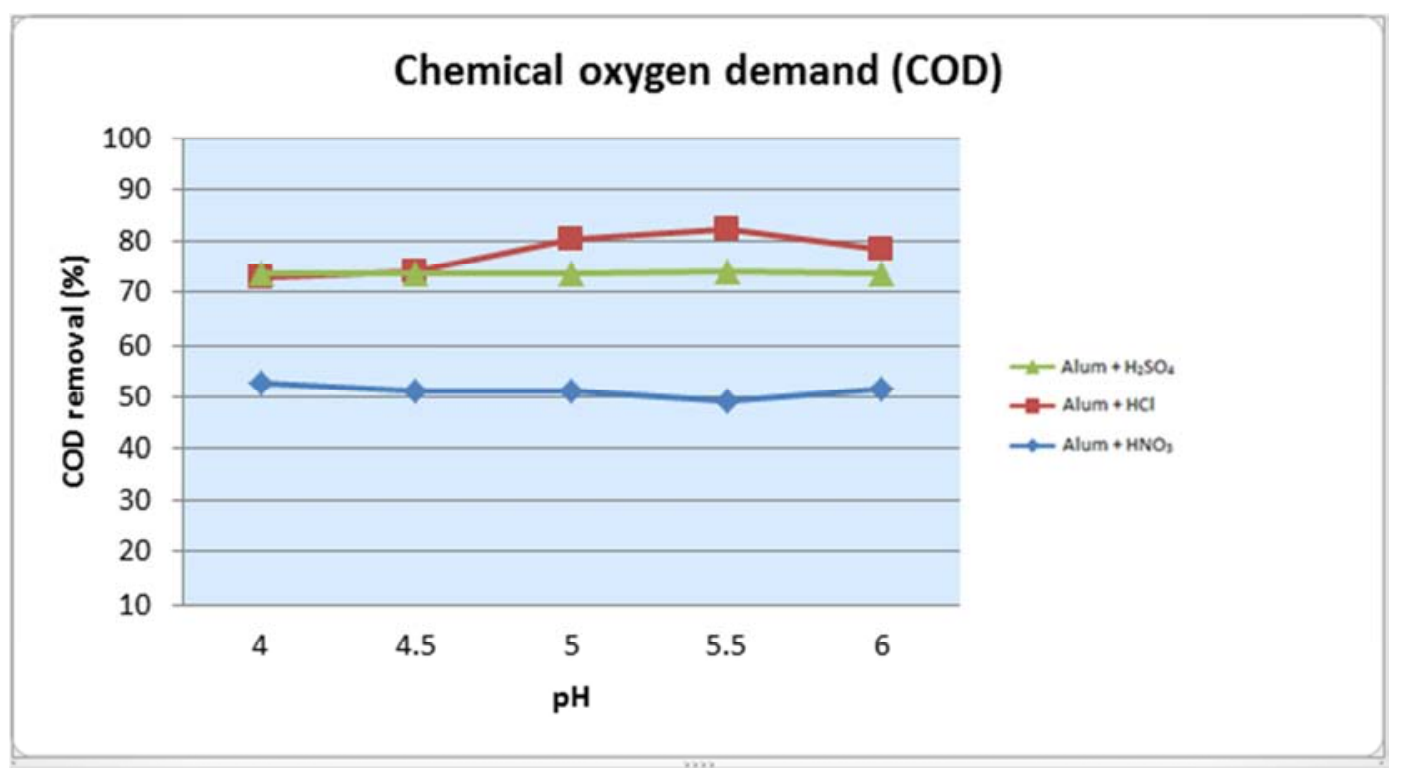

Figure 8. Reduction of $\mathrm{COD}$ as a function of $\mathrm{pH}\left(\mathrm{HCl}, \mathrm{HNO}_{3}\right.$ and $\left.\mathrm{H}_{2} \mathrm{SO}_{4}\right)$ with a fixed dose of alum.

Table 5. EC with alum using sulfuric acid, hydrochloric acid, and nitric acid.

\begin{tabular}{llll}
\hline EC with alum performance (\%) & & & \\
\hline Parameter & $\mathbf{H N O}_{3}$ & $\mathbf{H}_{2} \mathbf{S O}_{4}$ & HCl \\
\hline Turbidity & 5.5 & 19.7 & 5.6 \\
OM & 63.9 & 60.8 & 61.8 \\
CD & 16.7 & 16.7 & 50 \\
COD & 74.2 & 49 & 82.6 \\
\hline
\end{tabular}

In preliminary observation, we noticed that the flocs appeared only late, they are very fine and difficult to decant after 30 min. As shown in Figures. 5-8, the results obtained proved that the low $\mathrm{pH}$ coagulation process is effective towards the reduction of the parameters examined. The optimum of the elimination corresponds to a $\mathrm{pH}$ of 5.5 with the reduction rates mentioned in Table 5 .

\subsubsection{Ferric Chloride Experiments}

For alum, the optimal $\mathrm{pH}$ of coagulation was identified as the $\mathrm{pH}$ at which there was the highest removal of turbidity (Figure 9), OM (Figure 10), CD (Figure 11), and COD (Figure 12).

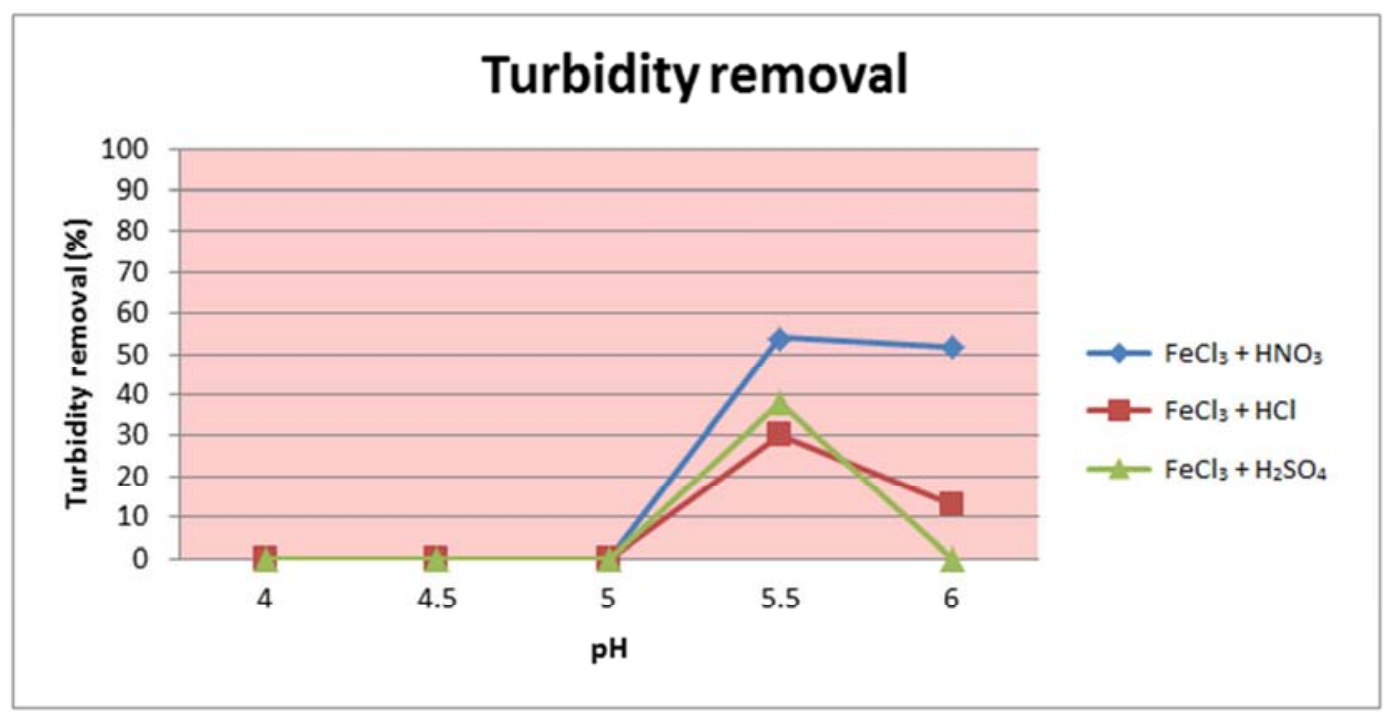

Figure 9. Reduction of turbidity as a function of $\mathrm{pH}\left(\mathrm{HCl}, \mathrm{HNO}_{3}\right.$ and $\left.\mathrm{H}_{2} \mathrm{SO}_{4}\right)$ with a fixed dose of $\mathrm{FeCl}_{3}$. 


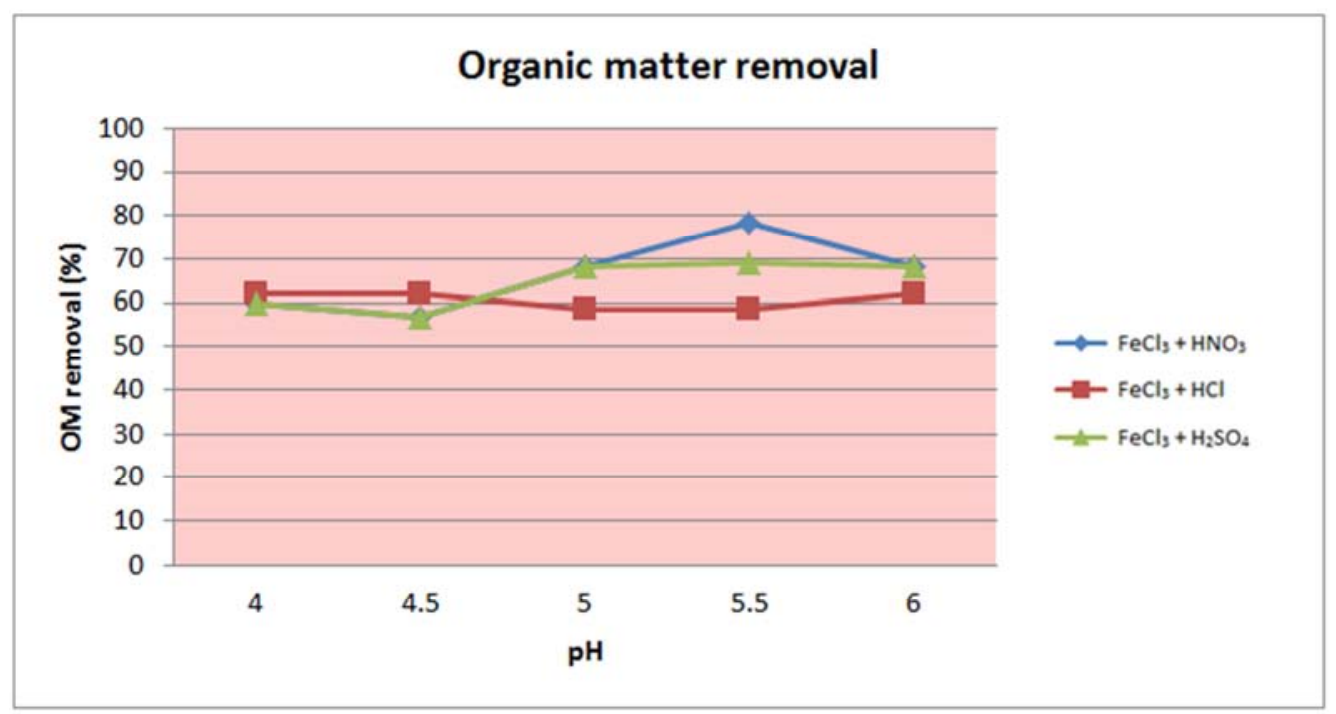

Figure 10. Reduction of $\mathrm{OM}$ as a function of $\mathrm{pH}\left(\mathrm{HCl}, \mathrm{HNO}_{3}\right.$ and $\left.\mathrm{H}_{2} \mathrm{SO}_{4}\right)$ with a fixed dose of $\mathrm{FeCl}_{3}$.

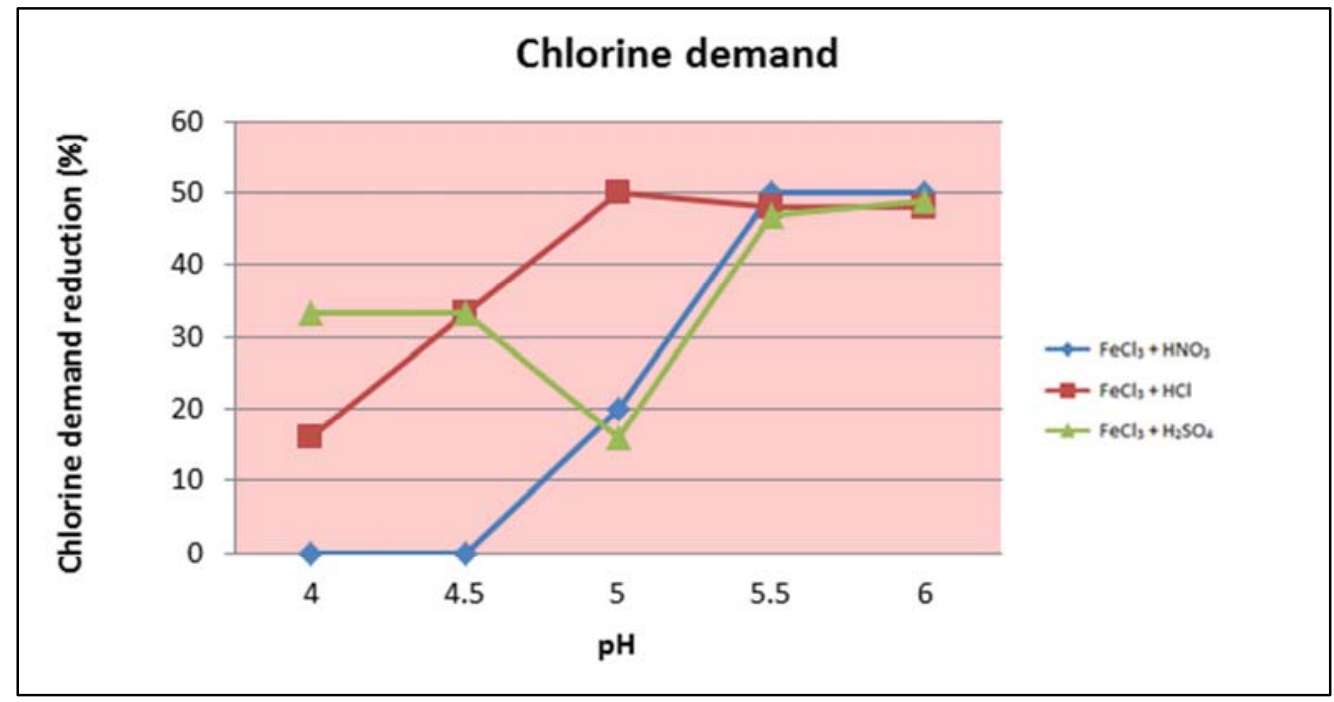

Figure 11. Reduction of $\mathrm{CD}$ as a function of $\mathrm{pH}\left(\mathrm{HCl}, \mathrm{HNO}_{3}\right.$ and $\left.\mathrm{H}_{2} \mathrm{SO}_{4}\right)$ with a fixed dose of $\mathrm{FeCl}_{3}$.

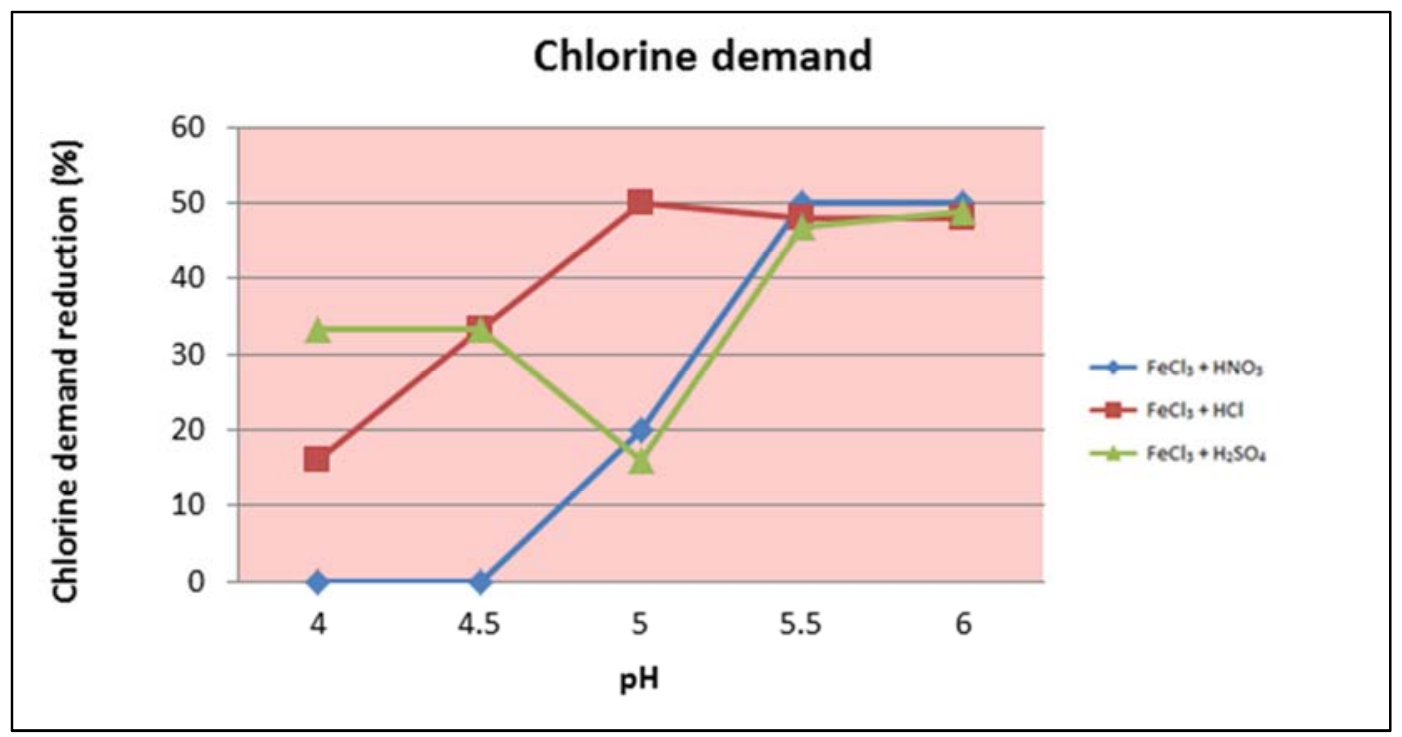

Figure 12. Reduction of $\mathrm{COD}$ as a function of $\mathrm{pH}\left(\mathrm{HCl}, \mathrm{HNO}_{3}\right.$ and $\left.\mathrm{H}_{2} \mathrm{SO}_{4}\right)$ with a fixed dose of $\mathrm{FeCl}_{3}$. 
The different water samples from the GD coagulated at fixed doses of ferric chloride $(50 \mathrm{mg} / \mathrm{L})$ and at increasing $\mathrm{pH}$ show the appearance of large dense flocs (rapid settling) between $\mathrm{pH} 5.5$ and 6. As shown in Figures. 9-12, the optimum of the elimination of the various parameters corresponds to a $\mathrm{pH}$ of 5.5 with a reduction rate listed in Table 6.

Table 6. EC with ferric chloride using sulfuric acid, hydrochloric acid, and nitric acid.

\begin{tabular}{|c|c|c|c|}
\hline \multicolumn{4}{|c|}{ EC with ferric chloride performance (\%) } \\
\hline Parameter & $\mathrm{HNO}_{3}$ & $\mathrm{H}_{2} \mathrm{SO}_{4}$ & HCl \\
\hline Turbidity & 54 & 38 & 30 \\
\hline OM & 78.3 & 69 & 58.7 \\
\hline $\mathrm{CD}$ & 50 & 50 & 50 \\
\hline COD & 100 & 91 & 87 \\
\hline
\end{tabular}

As seen in Table 6, the results obtained demonstrate clearly that the application of $\mathrm{FeCl}_{3}$ with the addition of $\mathrm{HNO}_{3}$ for $\mathrm{pH}$ adjustment to 5.5 is the best suited for the reduction of turbidity, $\mathrm{OM}, \mathrm{COD}, \mathrm{BOD}_{5}$, and microorganisms. In terms of efficiency, $\mathrm{H}_{2} \mathrm{SO}_{4}$ and $\mathrm{HCl}$ arrive at the second position.

\subsection{Alkaline Coagulation (AC) with Ferric Chloride and Alum}

Since the GD water is well-known for its high salinity and hardness, we thought to examine the effect of adding a base to the water in order to increase its $\mathrm{pH}$ before the injection of the coagulant to illustrate the effect of hydroxyl ions $\left(\mathrm{OH}^{-}\right)$on the precipitation of $\mathrm{Mg}^{2+}$ and $\mathrm{Ca}^{2+}$ ions. In other words, the experimental procedure adopted in this part of this study is the opposite of what was done with the EC based on the acidification of water before coagulation. The results obtained are illustrated and discussed in the following.

For alum, the obtained results are shown in Figures. 13-16.

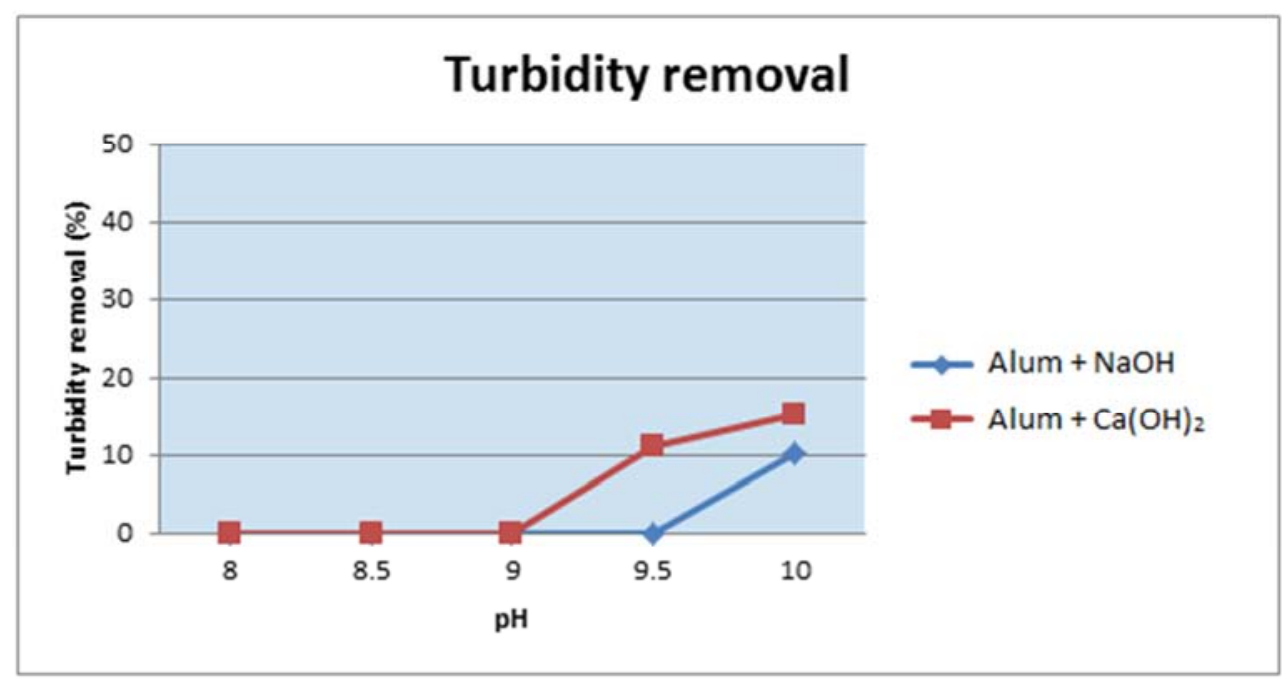

Figure 13. Removal of turbidity as a function of basic $\mathrm{pH}\left(\mathrm{Ca}(\mathrm{OH})_{2}\right.$ and $\left.\mathrm{NaOH}\right)$ with a fixed dose of alum.

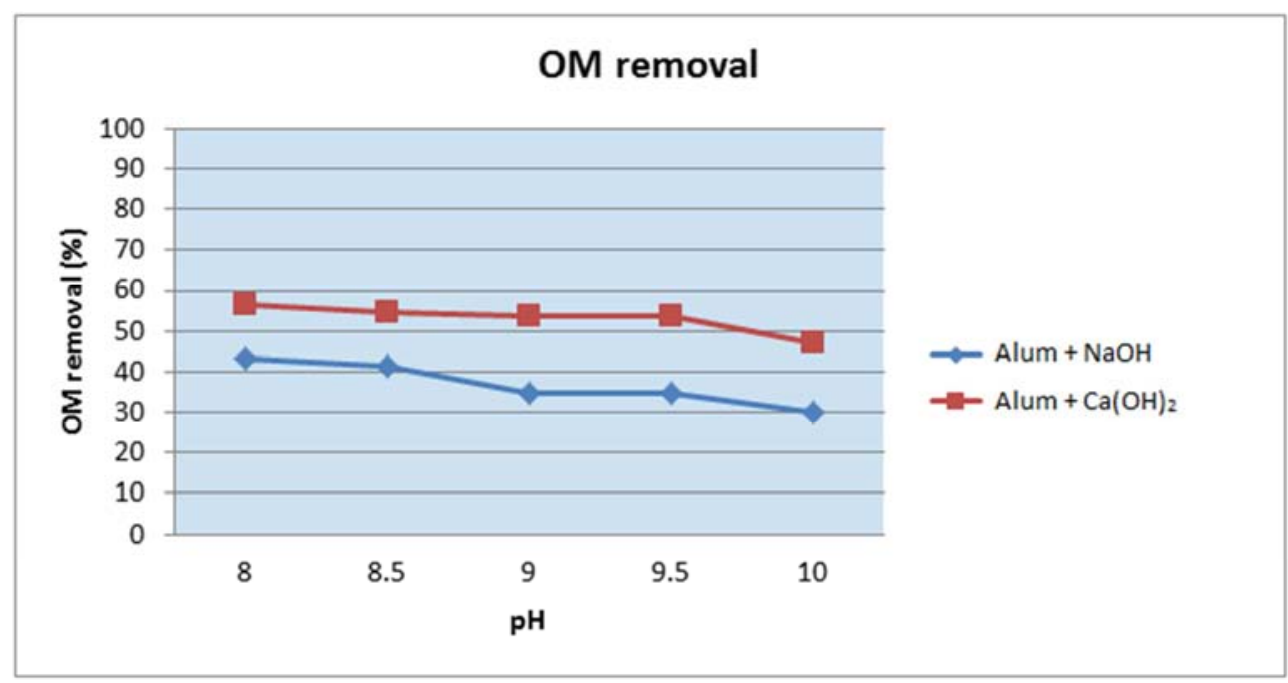

Figure 14. Removal of $\mathrm{OM}$ as a function of basic $\mathrm{pH}\left(\mathrm{Ca}(\mathrm{OH})_{2}\right.$ and $\left.\mathrm{NaOH}\right)$ with a fixed dose of alum. 


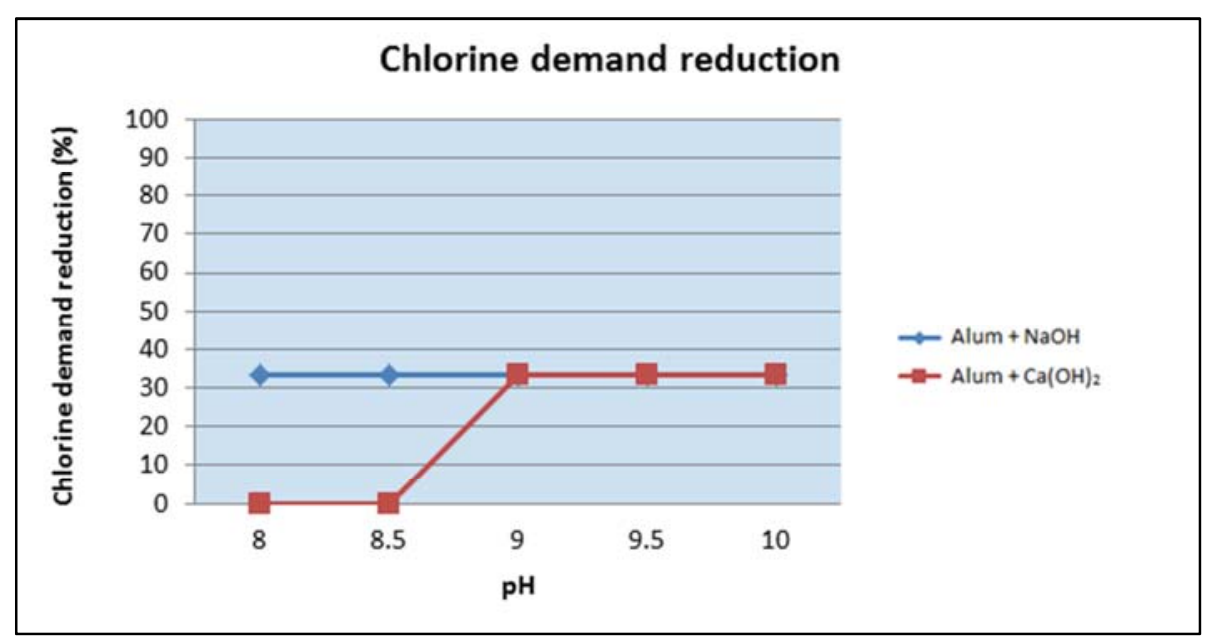

Figure 15. Reduction of $\mathrm{CD}$ as a function of basic $\mathrm{pH}\left(\mathrm{Ca}(\mathrm{OH})_{2}\right.$ and $\left.\mathrm{NaOH}\right)$ with a fixed dose of alum.

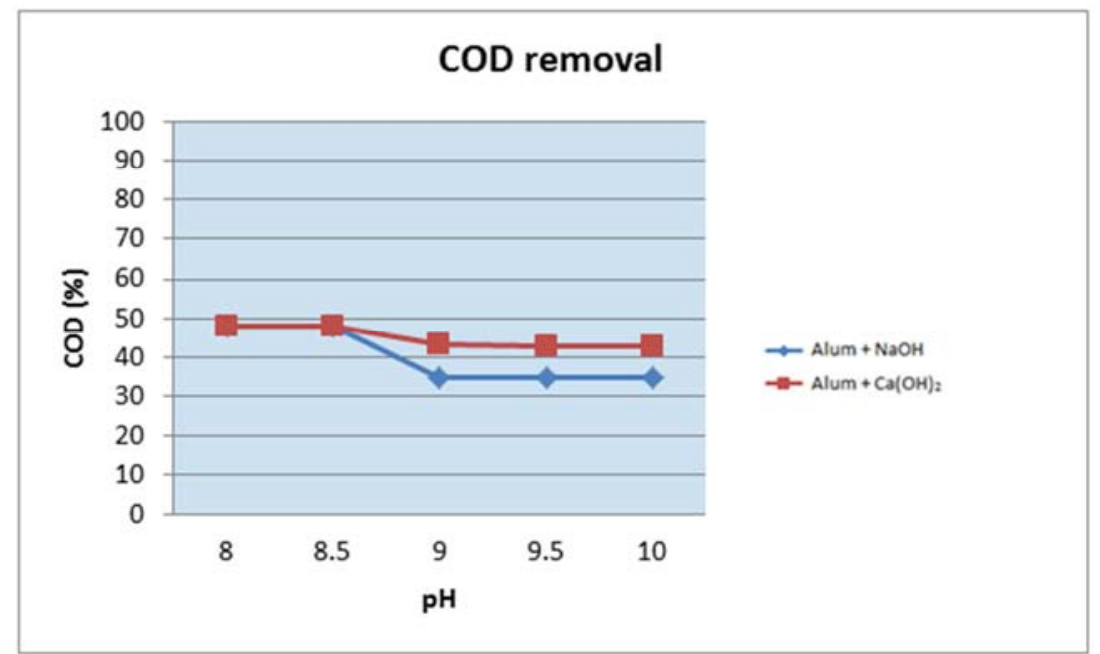

Figure 16. Removal of $\mathrm{COD}$ as a function of basic $\mathrm{pH}\left(\mathrm{Ca}(\mathrm{OH})_{2}\right.$ and $\left.\mathrm{NaOH}\right)$ with a fixed dose of alum.

Table 7. Alkaline coagulation $(A C)$ with alum using lime and $\mathrm{NaOH}$.

\begin{tabular}{lll}
\hline \multicolumn{2}{l}{ AC with alum performance (\%) } \\
\hline Parameter & Lime $\left(\mathbf{C a}(\mathbf{O H})_{2}\right)$ & $\mathbf{N a O H}$ \\
\hline Turbidity & 15.2 & 10.2 \\
OM & 56.7 & 43.3 \\
CD & 33.3 & 33.3 \\
COD & 47.9 & 47.9 \\
\hline
\end{tabular}

All the tests show that alum has a good coagulation capacity in the presence of lime and $\mathrm{NaOH}$ at $\mathrm{pH} 8$, but at much lower levels than with the acids tested previously. The alum performances may be listed in Table 7 .

An increase in the volume of sludge at the end of settling is noticed.

For ferric chloride, the obtained results are shown in Figures. 17-20.

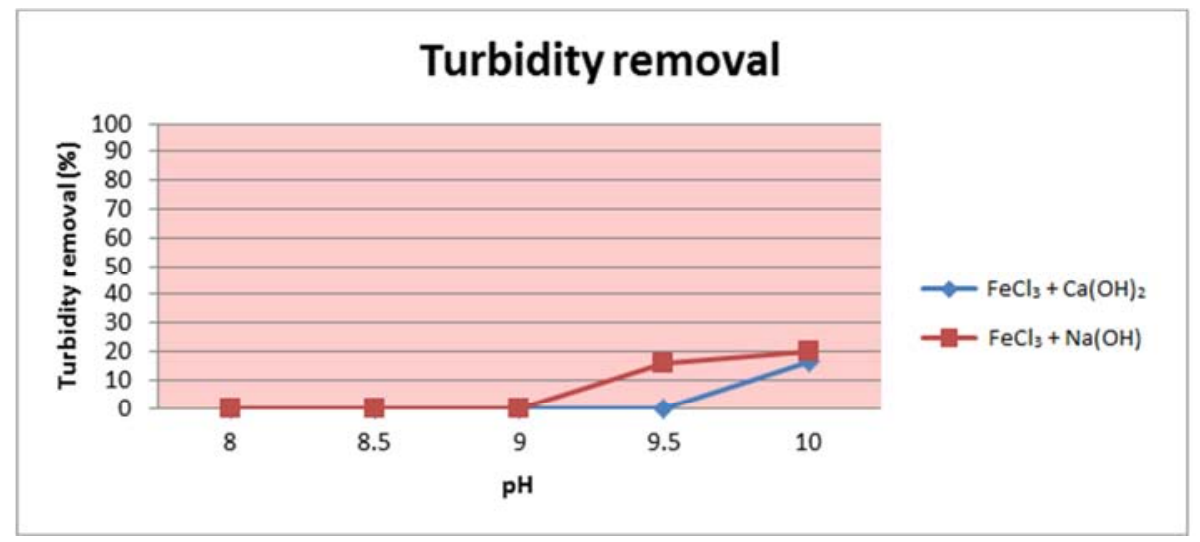

Figure 17. Removal of turbidity as a function of basic $\mathrm{pH}\left(\mathrm{Ca}(\mathrm{OH})_{2}\right.$ and $\left.\mathrm{NaOH}\right)$ with a fixed dose of ferric chloride. 


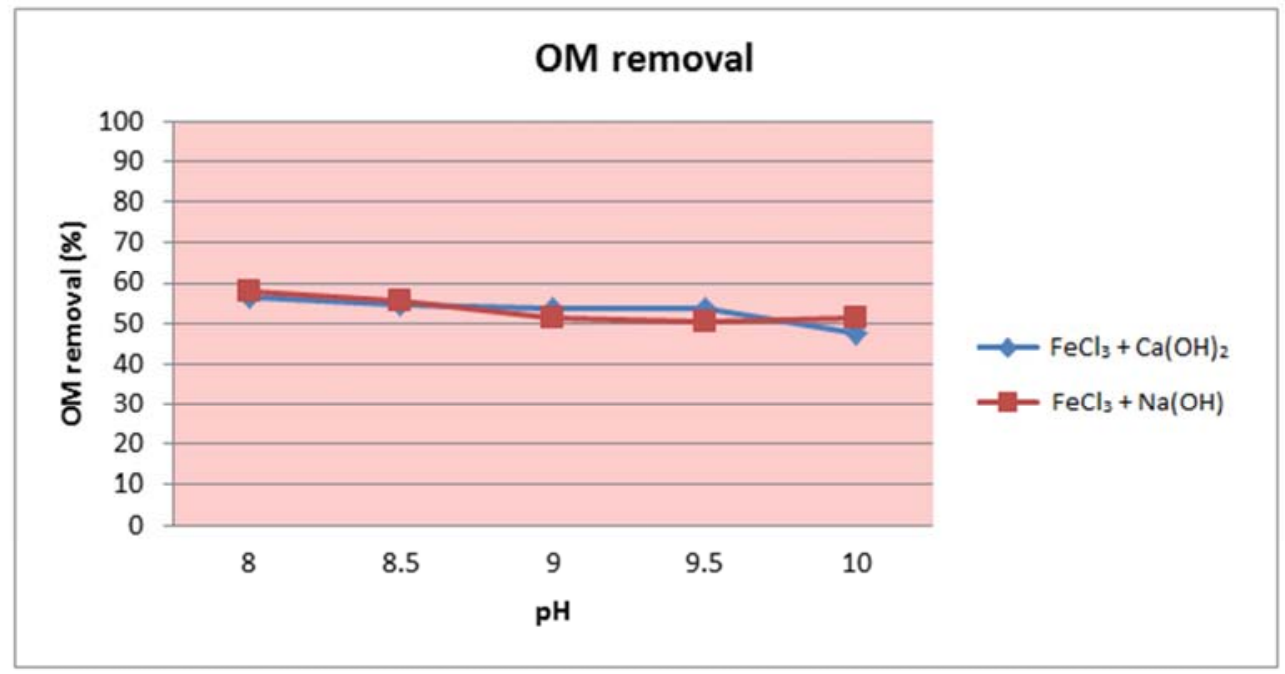

Figure 18. Removal of $\mathrm{OM}$ as a function of basic $\mathrm{pH}\left(\mathrm{Ca}(\mathrm{OH})_{2}\right.$ and $\left.\mathrm{NaOH}\right)$ with a fixed dose of ferric chloride.

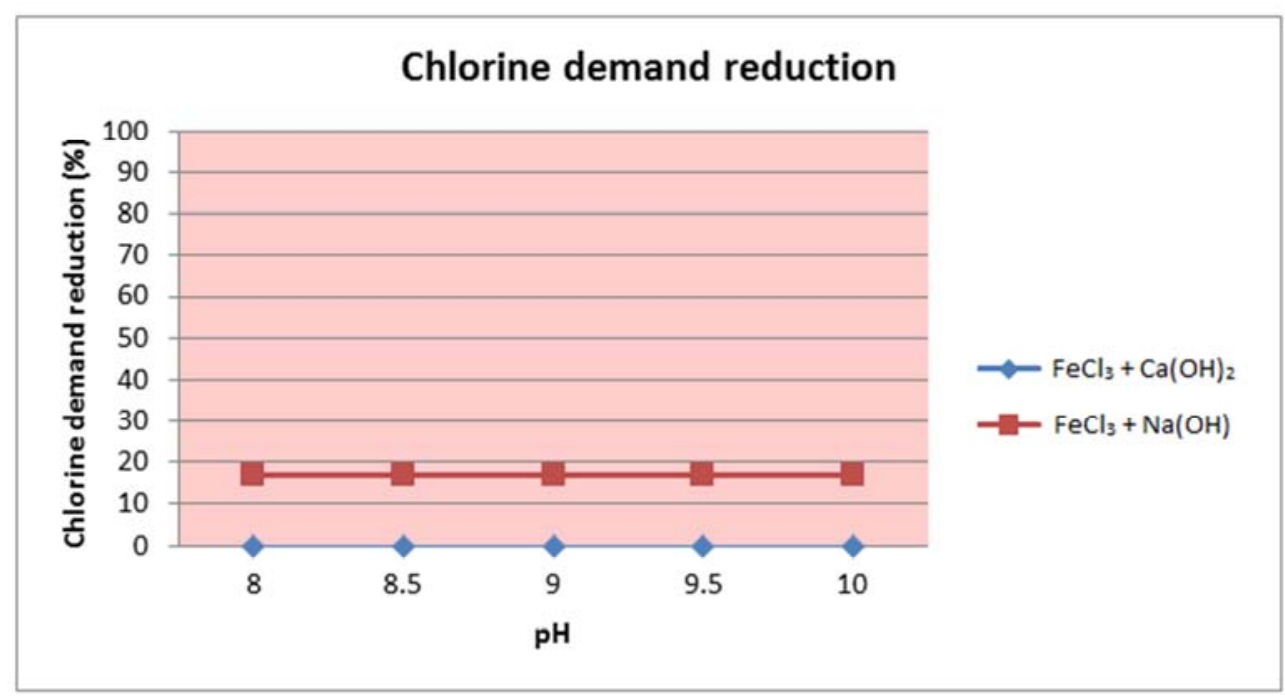

Figure 19. Reduction of $\mathrm{CD}$ as a function of basic $\mathrm{pH}\left(\mathrm{Ca}(\mathrm{OH})_{2}\right.$ and $\left.\mathrm{NaOH}\right)$ with a fixed dose of ferric chloride.

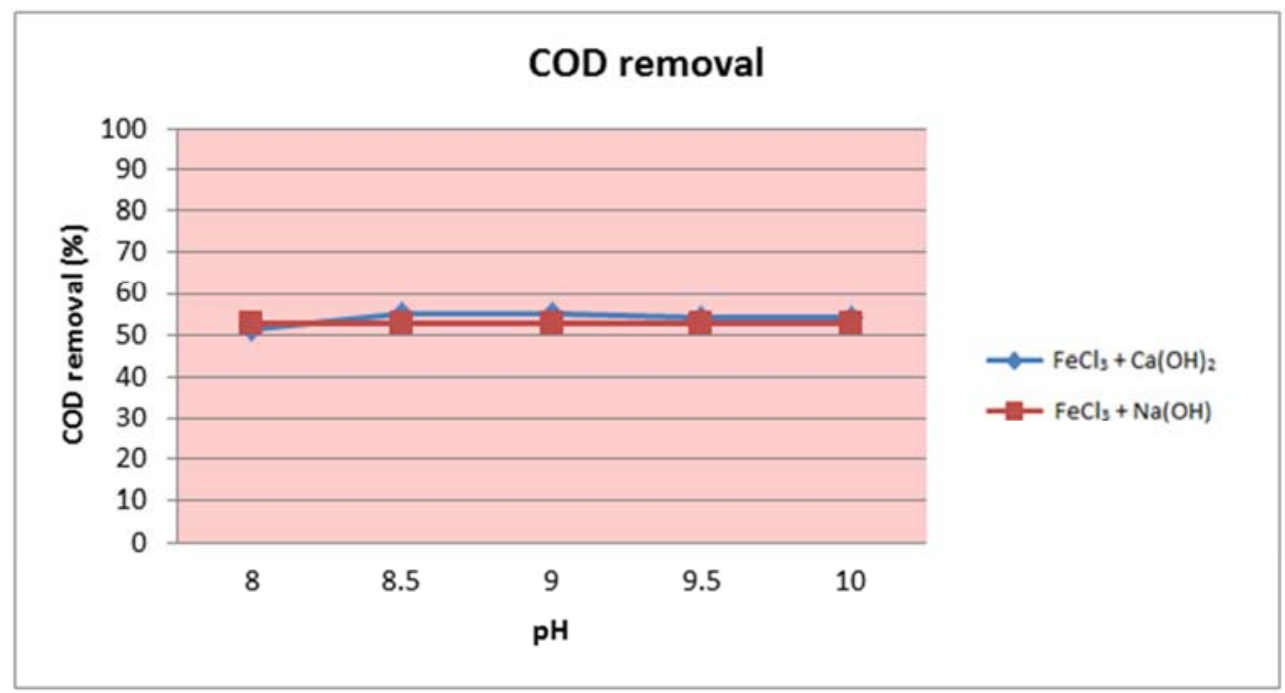

Figure 20. Removal of $\mathrm{COD}$ as a function of basic $\mathrm{pH}\left(\mathrm{Ca}(\mathrm{OH})_{2}\right.$ and $\left.\mathrm{NaOH}\right)$ with a fixed dose of ferric chloride.

As seen in Figures 17-20, the results with ferric chloride are similar to those of alum. The most appreciable removal is at 
pH 8 with either lime or soda. The best reduction rates are listed in Table 8.

Table 8. AC with ferric chloride using lime and $\mathrm{NaOH}$.

\begin{tabular}{lll}
\hline \multicolumn{3}{l}{ AC with ferric chloride performance $(\%)$} \\
\hline Parameter & Lime $\left(\mathbf{C a}(\mathbf{O H})_{2}\right)$ & NaOH \\
\hline Turbidity & 16.2 & 20 \\
OM & 56.7 & 57.7 \\
CD & 0 & 16.6 \\
COD & 52.6 & 56.7 \\
\hline
\end{tabular}

\subsection{General Discussion}

The results obtained show that, contrary to the use of coagulants alone (i.e., CC), lowering pH (i.e., EC [16]) makes it possible to have larger flocs settling more rapidly (the phenomenon of piston settling is more pronounced) especially with ferric chloride. This is because the floc formed by the iron-based coagulants is heavier than the alumina floc. In addition, it appears that ferric chloride is more effective in eliminating turbidity and $\mathrm{OM}$ than alum.

For the $\mathrm{AC}, \mathrm{Ca}(\mathrm{OH})_{2}$ and $(\mathrm{NaOH})$ used to alkalize the medium tend to form agglomerates of dense crystals decanting at high speed [23]. In addition, a decrease in total hardness and total alkalinity is observed; this can result in maximum precipitation of metal hydroxide $\left(\mathrm{Al}(\mathrm{OH})_{3(\mathrm{~s})}\right.$ or $\left.\mathrm{Fe}(\mathrm{OH})_{3(\mathrm{~s})}\right)$ during flocculation and decantation as well as an increase in sludge production [32]. Table 9 presents the softening efficiency of the two bases, $\mathrm{Ca}(\mathrm{OH})_{2}$ and $\mathrm{NaOH}$.

Table 9. Softening efficiency of the two bases, $\mathrm{Ca}(\mathrm{OH})_{2}$ and $\mathrm{NaOH}$.

\begin{tabular}{|c|c|c|c|c|c|c|}
\hline \multirow[b]{2}{*}{ Coagulant } & \multicolumn{3}{|l|}{$\mathrm{NaOH}$} & \multicolumn{3}{|l|}{$\mathrm{Ca}(\mathrm{OH})_{2}$} \\
\hline & $\begin{array}{l}\text { Total hardness } \\
\text { removal }(\%)\end{array}$ & Ca removal (\%) & Mg removal (\%) & $\begin{array}{l}\text { Total hardness } \\
\text { removal }(\%)\end{array}$ & Ca removal $(\%)$ & Mg removal (\%) \\
\hline $\mathrm{FeCl}_{3}$ & 41.3 & 46 & 41 & 0.1 & 0.1 & 0.1 \\
\hline Alum & 40 & 46 & 39.8 & 13.2 & 0.01 & 0.1 \\
\hline
\end{tabular}

The lime $\left(\mathrm{Ca}(\mathrm{OH})_{2}\right)$ did not give good results; maybe it would be necessary to go to higher $\mathrm{pH}$ and to eliminate the excess of lime by addition of $\mathrm{CO}_{2}$.

\section{Conclusions}

The main points drawn from this work are listed as below:

This study demonstrated the effectiveness of GD water treatment by the EC process compared to CC.

The results obtained confirm the bibliographic data concerning the elimination of organic compounds for $\mathrm{pH}$ levels globally between 5 and 7 depending on the nature of the coagulant. Indeed, it has been demonstrated that each of the two coagulants studied (alum and $\mathrm{FeCl}_{3}$ ) is effective for remarkable reductions in $\mathrm{OM}$ of $36 \%$ and $47.4 \%$, respectively. Turbidity, pathogenic microorganisms, COD, $\mathrm{BOD}_{5}$, chlorophyll $a$, and $\mathrm{CD}$ are eliminated at significant rates.

However, EC, by slightly acidifying water, gave better removal efficiencies of the studied parameters. Indeed, the best abatement of OM is about $78 \%$ when water is treated with ferric chloride at $\mathrm{pH} 5.5$, lowered with nitric acid. The observed disadvantage here is the residual nitrate, which existed in the raw water at only low level. On the other hand, at the same $\mathrm{pH}$, the reduction of the $\mathrm{OM}$ is $64 \%$ when alum is used as coagulant.

In addition, the data collected have led to the conclusion that the physicochemical quality of the GD water has a high salinity and lowering its $\mathrm{pH}$ (EC) does not affect it at all. On the other hand, its $\mathrm{pH}$ elevation (AC) considerably reduces its total hardness which is $41 \%$ with $\mathrm{NaOH}$. Such a performance advantageously positions this total hardness reduction technology among the possible solutions to the problems associated with total hardness. This observation suggests that it could attract the attention of stakeholders in the water treatment. This is all the more the case when one considers that, at first glance, the additional expenses associated with the implementation and operation of the process do not seem to be an insurmountable burden, especially in view of the fact that the OM removal of the treated water is paramount.

\section{Acknowledgements}

This study was supported by the Saudi Ministry of Education under the framework of the National Initiative on Creativity and Innovation Project (2440-81441-2017) in Saudi Universities. The authors gratefully acknowledge the support of their research program.

\section{List of Abbreviations}

$\begin{array}{ll}\text { AC } & \text { Alkaline coagulation } \\ \text { BOD }_{5} & \text { Biological oxygen demand } \\ \text { CC } & \text { Conventional coagulation } \\ \text { CD } & \text { Chlorine demand } \\ \text { COD } & \text { Chemical oxygen demand } \\ \text { EC } & \text { Enhanced coagulation } \\ \text { GD } & \text { Ghrib Dam } \\ \text { GDWTP } & \text { Ghrib Dam Water Treatment Plant } \\ \text { NOM } & \text { Natural organic matter } \\ \text { OM } & \text { Organic matter }\end{array}$

\section{References}

[1] D. Ghernaout, The Holy Koran Revelation: Iron is a "sent down" metal, Am. J. Environ. Prot. 6 (2017) 101-104.

[2] D. Ghernaout, The hydrophilic/hydrophobic ratio vs. dissolved organics removal by coagulation - A review, J. King Saud Univ. - Sci. 26 (2014) 169-180.

[3] D. Ghernaout, B. Ghernaout, From chemical disinfection to electrodisinfection: The obligatory itinerary? Desalin. Water Treat. 16 (2010) 156-175. 
[4] D. Ghernaout, Environmental principles in the Holy Koran and the Sayings of the Prophet Muhammad, Am. J. Environ. Prot. 6 (2017) 75-79.

[5] B. Ghernaout, D. Ghernaout, A. Saiba, Algae and cyanotoxins removal by coagulation/flocculation: A review, Desalin. Water Treat. 20 (2010) 133-143.

[6] D. Ghernaout, Entropy in the Brownian motion (BM) and coagulation background, Colloid Surface Sci. 2 (2017) 143-161.

[7] D. Ghernaout, B. Ghernaout, M. W. Naceur, Embodying the chemical water treatment in the green chemistry - A review, Desalination 271 (2011) 1-10.

[8] D. Ghernaout, Water reuse (WR): The ultimate and vital solution for water supply issues, Intern. J. Sustain. Develop. Res. 3 (2017) 36-46.

[9] D. Ghernaout, Increasing trends towards drinking water reclamation from treated wastewater, World J. Appl. Chem. 3 (2018) 1-9.

[10] D. Ghernaout, Magnetic field generation in the water treatment perspectives: An overview, Int. J. Adv. Appl. Sci. 5 (2018) 193-203.

[11] D. Ghernaout, M. Aichouni, A. Alghamdi, Applying Big Data (BD) in water treatment industry: A new era of advance, Int. J. Adv. Appl. Sci. 5 (2018) 89-97.

[12] D. Ghernaout, S. Moulay, N. Ait Messaoudene, M. Aichouni, M. W. Naceur, A. Boucherit, Coagulation and chlorination of NOM and algae in water treatment: A review, Intern. J. Environ. Monit. Analy. 2 (2014) 23-34.

[13] A. Boucherit, S. Moulay, D. Ghernaout, A. I. Al-Ghonamy, B. Ghernaout, M. W. Naceur, N. Ait Messaoudene, M. Aichouni, A. A. Mahjoubi, N. A. Elboughdiri, New trends in disinfection by-products formation upon water treatment, J. Res. Develop. Chem., 2015, DOI: 10.5171/2015.628833.

[14] D. Ghernaout, Water treatment chlorination: An updated mechanistic insight review, Chem. Res. J. 2 (2017) 125-138.

[15] D. Ghernaout, Disinfection and DBPs removal in drinking water treatment: A perspective for a green technology, Int. J. Adv. Appl. Sci. 5 (2018) 108-117.

[16] D. Ghernaout, B. Ghernaout, A. Kellil, Natural organic matter removal and enhanced coagulation as a link between coagulation and electrocoagulation, Desalin. Water Treat. 2 (2009) 209-228.

[17] D. Ghernaout, A. Badis, G. Braikia, N. Matâam, M. Fekhar, B. Ghernaout, A. Boucherit, Enhanced coagulation for algae removal in a typical Algeria water treatment plant, Environ. Eng. Manag. J. 16 (2017) 2303-2315.

[18] D. Ghernaout, M. W. Naceur, Ferrate(VI): In situ generation and water treatment - A review, Desalin. Water Treat. 30 (2011) 319-332.

[19] D. Ghernaout, B. Ghernaout, On the concept of the future drinking water treatment plant: Algae harvesting from the algal biomass for biodiesel production-A Review, Desalin. Water Treat. 49 (2012) 1-18.

[20] D. Ghernaout, The best available technology of water/wastewater treatment and seawater desalination: Simulation of the open sky seawater distillation, Green Sustain. Chem. 3 (2013) 68-88.

[21] D. Ghernaout, C. Benblidia, F. Khemici, Microalgae removal from Ghrib Dam (Ain Defla, Algeria) water by electroflotation using stainless steel electrodes, Desalin. Water Treat. 54 (2015) 3328-3337.

[22] D. Ghernaout, A. Simoussa, A. Alghamdi, B. Ghernaout, N. Elboughdiri, A. Mahjoubi, M. Aichouni, A. E. A. El-Wakil, Combining lime softening with alum coagulation for hard Ghrib dam water conventional treatment, Int. J. Adv. Appl. Sci. 5 (2018) 61-70.

[23] J. Rodier (2009), Analyse de l'eau, (in French), $9^{\text {th }}$ Ed., Dunod, Paris.

[24] ISO, https://www.iso.org/home.html (Accessed on 03/05/18).

[25] Wikipedia, 2018. Drinking water quality standards, https://en.wikipedia.org/wiki/Drinking_water_quality_standar ds (Accessed on 12/05/18).

[26] Wikipedia, 2018. Turbidity, https://en.wikipedia.org/wiki/Turbidity (Accessed on $12 / 05 / 18)$.

[27] D. Ghernaout, M. W. Naceur and A. Aouabed, On the dependence of chlorine by-products generated species formation of the electrode material and applied charge during electrochemical water treatment, Desalination 270 (2011) 9-22.

[28] D. Ghernaout, A. I. Al-Ghonamy, A. Boucherit, B. Ghernaout, M. W. Naceur, N. Ait Messaoudene, M. Aichouni, A. A. Mahjoubi, N. A. Elboughdiri, Brownian motion and coagulation process, Am. J. Environ. Prot. 4 (2015) 1-15.

[29] D. Ghernaout, C. Laribi, A. Alghamdi, B. Ghernaout, N. Ait Messaoudene, M. Aichouni, Decolorization of BF Cibacete Blue (CB) and Red Solophenyle 3BL (RS) Using Aluminum Sulfate and Ferric Chloride, World J. Appli. Chem. 3 (2018) $32-40$.

[30] D. Ghernaout, A. I. Al-Ghonamy, M. W. Naceur, A. Boucherit, N. A. Messaoudene, M. Aichouni, A. A. Mahjoubi, N. A. Elboughdiri, Controlling coagulation process: From Zeta potential to streaming potential, Am. J. Environ. Prot. 4 (2015) 16-27.

[31] D. Ghernaout, A. Boucherit, Review of coagulation's rapid mixing for NOM removal, J. Res. Develop. Chem., 2015, DOI: $10.5171 / 2015.926518$.

[32] D. Ghernaout, B. Ghernaout, Sweep flocculation as a second form of charge neutralisation - A review, Desalin. Water Treat. 44 (2012) 15-28. 